\title{
European Stroke Initiative Recommendations for Stroke Management - Update 2003
}

\author{
The European Stroke Initiative Executive Committee and \\ the EUSI Writing Committee
}

\section{Key Words}

Stroke - Prevention - Acute stroke therapy - Stroke unit · Rehabilitation

\begin{abstract}
This article represents the update of 'European Stroke Initiative Recommendations for Stroke Management', first published in this Journal in 2000 . The recommendations are endorsed by the 3 European societies which are represented in the European Stroke Initiative: the European Stroke Council, the European Neurological Society and the European Federation of Neurological Societies. Copyright () 2003 S. Karger AG, Basel
\end{abstract}

\section{Introduction}

'European Stroke Initiative Recommendations for Stroke Management' was first published in this Journal in 2000. The first publication was well received and was followed by a lengthier supplement to Cerebrovascular Diseases. After 3 years, the European Stroke Initiative (EUSI) Executive Committee felt that there were enough new data to justify a complete revision of the recommendations. The EUSI Executive Committee also decided that the consensus for the recommendations should have a broader base and therefore invited several European stroke neurologists from different countries to join the writing group. The members of both, Writing Group and Executive Committee, met for 3 days in December 2002 in Heidelberg, Germany, and prepared the new recommendations. The recommendations from the EUSI published in 2000 [European Stroke Initiative, 2000] have now been completely revised and updated. In accordance with the European Neurological Society, the European Federation of Neurological Society and the European Stroke Council, which also represents the European Stroke Conference, they provide an overview of established or widely used therapeutic strategies as well as an evaluation of evolving, but not yet proven strategies. These are discussed in detail as well as classified according to their scientific levels of evidence. On the basis of such evidence, specific recommendations are made. Experts' opinions on several issues on stroke prevention and treatment can be assessed at the EUSI website free of charge at http://www.eusi-stroke.com. These lectures represent an extension of many issues discussed in these recommendations but have not passed the consensus process of the EUSI documents and therefore only reflect the opinion of the lecturing experts.

The levels of evidence in this article are defined by the same criteria as in the previous recommendations. They

For the European Stroke Initiative (EUSI) Executive Committee: Werner Hacke, Heidelberg, Germany; Markku Kaste, Helsinki, Finland; Julien Bogousslavsky, Lausanne, Switzerland; Michael Brainin, Maria Gugging, Austria; Angel Chamorro, Barcelona, Spain; Kennedy Lees, Glasgow, UK; Didier Leys, Lille, France; Hubert Kwiecinski, Warsaw, Poland; Danilo Toni, Rome, Italy.

The EUSI Writing Committee: Tom Skyhoj Olsen, Copenhagen, Denmark; Peter Langhorne, Glasgow, UK; Hans Christoph Diener, Essen, Germany; Michael Hennerici, Mannheim, Germany; Jose Ferro, Lisbon, Portugal; Johani Sivenius, Kuopio, Finland; Nils Gunnar Wahlgren, Stockholm, Sweden; Philip Bath, Nottingham, UK.

On behalf of the European Stroke Council, the European Neurological Society and the European Federation of Neurological Societies.

\begin{tabular}{ll}
\hline KARGER & ( ) 2003 S. Karger AG, Basel \\
Fax +4161306 1234 $34-9770 / 03 / 0164-0311 \$ 19.50 / 0$ \\
$\begin{array}{l}\text { E-Mail karger@karger.ch } \\
\text { www.karger.com }\end{array}$ & $\begin{array}{l}\text { Accessible online at: } \\
\text { www.karger.com/ced }\end{array}$
\end{tabular}

Werner Hacke, MD, PhD

Department of Neurology, University of Heidelberg, INF 400

DE-69120 Heidelberg (Germany)

Tel. +496221568210, Fax +496221565348

E-Mail werner_hacke@med.uni-heidelberg.de 
Table 1. Definitions of levels of evidence for these recommendations ([European Stroke Initiative, 2000], modified after Adams et al. [1994])

\begin{tabular}{|c|c|}
\hline $\begin{array}{l}\text { Level I } \\
\quad \text { Sources }\end{array}$ & $\begin{array}{l}\text { Highest level of evidence } \\
\text { a Primary endpoint of RCT with adequate } \\
\text { sample size } \\
\text { b Meta-analysis of qualitatively outstanding RCTs }\end{array}$ \\
\hline $\begin{array}{l}\text { Level II } \\
\quad \text { Sources }\end{array}$ & $\begin{array}{l}\text { Intermediate level of evidence } \\
\text { a Small randomised trials } \\
\text { b Predefined secondary endpoints of large RCTs }\end{array}$ \\
\hline $\begin{array}{l}\text { Level III } \\
\text { Sources }\end{array}$ & $\begin{array}{l}\text { Lower level of evidence } \\
\text { a Prospective case series with concurrent or } \\
\text { historical control } \\
\text { b Post hoc analyses of large RCTs }\end{array}$ \\
\hline $\begin{array}{l}\text { Level IV } \\
\quad \text { Sources }\end{array}$ & $\begin{array}{l}\text { Undetermined level of evidence } \\
\text { a Small uncontrolled case series } \\
\text { b General agreement despite lack of evidence }\end{array}$ \\
\hline
\end{tabular}

correspond to those published by the European Federation of Neurological Society [Hughes et al., 2001] and are listed in table 1 .

\section{Organisation of Stroke Care: Education, Referral, Stroke Units and Rehabilitation}

Acute stroke is one of the leading factors of morbidity and mortality worldwide. After cardiovascular disease, stroke ranks as either second or third most common cause of death in industrialised countries. In Europe, the crude death rate ranges from 63.5/100,000 (males, Switzerland, 1992) to $273.4 / 100,000$ (females, Russia, 1991). Such large differences in mortality between east and west in Europe have been noted [Stegmayr et al., 2000] and attributed to differences in risk factor expression with higher levels of hypertension and other risks in eastern countries as compared with the west, thus resulting in more severe strokes in Eastern Europe [Brainin et al., 2000]. Also within Western Europe, notable regional variations have been found [Wolfe et al., 2000]. Stroke as the most important cause of morbidity and long-term disability in Europe imposes an enormous economic burden. The average cost from first stroke to death has been calculated for several European countries [Kaste et al., 1998] and has for example in Sweden been shown to approximate 79,000 EUR [Asplund et al., 1993].

Over the past decades, acute stroke has increasingly been recognised as a medical emergency. Acute, postacute, and rehabilitation care of stroke patients in special- ised wards as well as revascularising therapies have been proven to be effective in acute ischaemic stroke. The establishment of a network consisting of acute stroke units, seamless continuation to post-acute care and rehabilitation, as well as further care in the community has become standard treatment in many European countries. Systems of care have emerged that include nation-wide concepts of stroke care units focussing on the acute care as in Austria or Germany [Weimar et al., 2002a; Brainin and Steiner 2003], and systems of stroke units focussing on comprehensive care including rehabilitation as in the UK or Scandinavia [Jorgensen et al., 1995; Kalra, 1995; Indredavik et al., 1997].

Several publications of European guidelines and consensus papers have been published over the past years: these include reports from the Pan European Consensus Meeting on Stroke Management [Aboderin et al., 1996], the European Ad Hoc Consensus Group [The European Ad Hoc Consensus Group, 1996, 1997], the Task Force on Acute Neurological Stroke Care of the European Federation of Neurological Societies [Brainin et al., 1997, 2000; Thomassen et al., in press], and the EUSI [European Stroke Initiative, 2000]. Among North American guidelines and treatment recommendations issued by the American Academy of Neurology are those for acute treatment [Adams et al., 1994, 2003], carotid surgery [Biller et al., 1998], management of transient ischaemic attacks (TIAs) [Feinberg et al., 1994] and primary prevention of stroke [Goldstein et al., 2001]. Earlier recommendations have been issued by the WHO [WHO Task Force on Stroke and Other Cerebrovascular Disorders, 1989].

\section{Education}

Many patients and relatives do not recognise the symptoms of stroke and do not realise that seeking treatment is urgent. Reasons for this shortcoming include a poor awareness of stroke by the victim or family, reluctance to seek immediate medical help, incorrect diagnosis by the paramedical service and perceiving stroke not as an emergency by medical personnel and the family physician [Becker et al., 2001; Yoon and Byles, 2002; Evenson et al., 2000]. These facts emphasise the need for continuous education. The aims of public education initiatives are to enable and encourage the general population to recognise immediately the symptoms of stroke, to realise that urgent medical attention is needed, and to use the emergency transportation services and immediately go to an adequately equipped hospital. Primary contact with gen-

\footnotetext{
$312 \quad$ Cerebrovasc Dis 2003;16:311-337
} 
eral practitioners may cause delays and prevent an early start of adequate therapy [Evenson et al., 2000]. Educational efforts should be directed to patients at risk for stroke, their families, caregivers or co-workers and to large employers [Wein et al., 2000]. Teaching the public about symptoms and signs of stroke is one of the highest priorities of public medical education.

Inaccurate initial diagnosis by professional groups represents a major problem. Ambulance dispatchers may have a false-positive assessment rate of up to $50 \%$, and even in trained paramedics, this rate is about 25\% [Kothari et al., 1997]. However, this result can be improved by adequate training [Kothari et al., 1997].

Physicians also need to be trained in the recognition of symptoms and signs of acute stroke and the necessity of immediate transportation to an adequately equipped unit. The medical personnel should be trained in recognising the acute presentations of ischaemic stroke and should be able to cope with the early complications after stroke. Training should include the ability to conduct a medical examination that focuses on the level of consciousness, presence of focal weakness, presence of seizure activity and recognition of aphasia and other major cognitive disturbances. The concept of 'time is brain' should be understood by all involved in the 'stroke chain of survival'. No waste of time should be allowed when the patient has arrived to hospital and written standards for in-hospital delays should be available in hospitals receiving patients with acute stroke. Although such pathways have not been shown to be effective by themselves [Kwan and Sandercock, 2003], they can be considered effective in preventing in-hospital delays.

\section{Referral}

Stroke is a medical and occasionally also a surgical emergency. Successful care of the acute stroke victim begins with the recognition both by the public and the health professional that stroke is an emergency, like acute myocardial infarction (MI) and trauma. The majority of stroke patients do not receive adequate therapy because they do not reach the hospital soon enough [Barber et al., 2001]. Successful care of the acute stroke victim as an emergency depends on a 4-step chain: (1) rapid recognition of and reaction to stroke warning signs, (2) immediate use of emergency medical system (EMS) services, (3) priority transport with notification of the receiving hospital and (4) rapid and accurate diagnosis and treatment at the hospital.
Failure to recognise stroke symptoms and consulting a primary physician delay the interval between stroke onset and hospital arrival [Ferro et al., 1994; Wester et al., 1999; Derex et al., 2002; Harraf et al., 2002].

Once stroke symptoms are suspected, patients or their proxies should call the EMS. Ambulance transportation decreases the delay of arrival at the hospital after stroke onset (level III). Helicopter transport is playing an increasing role in the transfer of patients with stroke between hospitals and should be activated earlier [Thomas et al., 2002]. The EMS should have an electronic validated algorithm of questions to diagnose stroke during the phone interview with the patient/proxy [Porteous et al., 1999; Camerlingo et al., 2001]. Patients with onset of stroke symptoms within less than $3 \mathrm{~h}$ should be given priority in evaluation/transportation by the EMS. The EMS ambulance dispatchers should be able to recognise stroke symptoms and signs [Kothari et al., 1997] and identify and provide appropriate help for patients who need emergent care because of impaired consciousness, seizures, vomiting, haemodynamic instability or other early complication or co-morbidity of stroke.

If a general practitioner or other doctor receives a call or consults a patient with suspected stroke, he/she should recommend/arrange emergent transportation, preferably through the EMS, to the nearest emergency room of a hospital providing organised acute stroke care or a stroke unit if available. The EMS ambulance dispatchers should inform the stroke unit personnel that they are going to refer a stroke patient and describe the clinical status.

The initial evaluation of stroke patients can be made by emergency room doctors. In fact, emergency room doctors can correctly make the diagnosis of stroke in about $90 \%$ of cases [Ferro et al., 1998].

Patients with subarachnoid haemorrhage should be referred urgently to a hospital where neurosurgical treatment, neuroradiological interventions and intensive care are available.

\section{Recommendations}

1 Stroke patients should be treated in stroke units (level I). Therefore, suspected stroke victims should be transported without delay to the nearest medical centre with an available stroke unit, or to a hospital providing organised acute stroke care if a stroke unit is not available.

2 Once stroke symptoms are suspected, patients or their proxies should call the EMS or a similar system (level III).

3 Patients with subarachnoid haemorrhage should be referred urgently to a centre with facilities for neurosurgical treatment, neuroradiological interventions and neurointensive care (level I). 


\section{Stroke Units}

Stroke care should take place in a stroke unit. A metaanalysis by the Stroke Unit Trialists' Collaboration [Stroke Unit Trialists' Collaboration, 2002] showed a $18 \%$ relative reduction in mortality, a reduction in death or dependence and a reduction in death or need of institutional care when treated in a stroke unit in comparison with a general medical ward (level I). The absolute changes indicated a $3 \%$ reduction in all cause mortality [numbers needed to treat (NNT) 33], a 3\% reduction in the need for nursing home care, and a $6 \%$ increase in the number of independent survivors (NNT 16). All types of patients with stroke benefit from treatment and rehabilitation in stroke units: males and females, young and elderly stroke patients and patients with mild, moderate and severe strokes.

A stroke unit consists of a hospital unit or part of a hospital unit that exclusively or nearly exclusively takes care of stroke patients. A survey across Europe showed that various forms of stroke unit care exist [Brainin et al., 2000]. Most of such stroke units provide a co-ordinated multidisciplinary approach to treatment and care. The core disciplines of such a multidisciplinary team are: medical treatment, nursing, physiotherapy, occupational therapy, speech and language therapy and social work. The multidisciplinary team should have a specialist interest in stroke management and work in a coordinated way (through regular meetings to plan patient care). Programmes of regular staff education and training should be provided.

The typical components of care in the stroke unit trials [Langhorne et al., 2002] were as follows: (a) assessment medical assessment and diagnosis including computerised tomography (CT) scanning, early assessment of nursing and therapy needs; (b) early management policies early mobilisation, prevention of complications, treatment of hypoxia, hyperglycaemia, pyrexia and dehydration, and (c) ongoing rehabilitation policies (coordinated multidisciplinary team care, early assessments of needs after discharge).

Stroke units are described in several categories: (1) the acute stroke unit admitting patients acutely and continuing treatment several days but usually less than 1 week; (2) the comprehensive stroke unit admitting patients acutely and continuing treatment and rehabilitation for several weeks if necessary; (3) the rehabilitation stroke unit admitting patients after a delay of 1 or 2 weeks and continuing treatment and rehabilitation for several weeks or months if necessary, and (4) a mobile stroke team is a mobile team offering stroke care and treatment to stroke patients at a variety of wards. Such teams are usually established in hospitals where stroke units are not available.

Of these, only the comprehensive stroke unit and the rehabilitation stroke unit have proven effectiveness in terms of reduced mortality and handicap [Stroke Unit Trialists' Collaboration, 2002].

The size of a stroke unit should be adequate to provide specialist multidisciplinary stroke unit care for the whole duration of hospital admission. In practice, this is often achieved with a single comprehensive unit (in smaller hospitals) or a combination of acute unit and rehabilitation units (in larger hospitals). Further evidence is needed to recommend type and size of the most effective stroke units in more detail (table 2).

\section{Recommendations}

1 Stroke patients should be treated in stroke units (level I).

2 Stroke units should provide co-ordinated multidisciplinary care provided by medical, nursing and therapy staff who specialise in stroke care (level I).

\section{Emergency Management}

The time window for treatment of patients with acute stroke is narrow. Acute emergency management of stroke therefore requires parallel processes at different levels of patient management. For example, acute assessment of neurological and vital functions parallels treatment of acutely life-threatening conditions. The selection of special treatment strategies may already be ongoing before the final decision on the subtype of acute stroke has been made. Time is the most important factor, especially the minutes and first hours after stroke onset.

The acute stroke patient, even the one with milder symptoms, must be recognised as an urgently ill medical patient [Brott et al., 1994; Brott and Reed, 1989; Adams et al., 1994]. The patient has to be transported to an emergency unit, and the examining physician must assess the stroke patient with the priority for a life-threatening and disabling illness. Only a minority of the stroke patients present with an immediate life-threatening condition, but many have severe abnormalities in basic physiologic functions. Symptoms and signs which may predict later complications such a space-occupying infarction or bleeding, recurrent stroke, and medical conditions such as hypertensive crisis, co-existing MI, aspiration pneumonia and renal failure must be recognised early. Also, early assess- 
Table 2. Requirements for stroke management

Minimum requirements for centres managing acute stroke patients

1 Availability of 24-hour CT scanning

2 Established stroke treatment guidelines and operational procedures

3 Close co-operation of neurologists, internists and rehabilitation experts

4 Specially trained nursing personnel

5 Early multidisciplinary rehabilitation including speech therapy, occupational therapy and physical therapy

6 Established network of rehabilitation facilities to provide a continuous process of care

7 Neurosonological investigations within $24 \mathrm{~h}$ (extracranial vessels, colour-coded duplex sonography)

8 ECG

9 Laboratory examinations (including coagulation parameters)

10 Monitoring of blood pressure, ECG, oxygen saturation, blood glucose, body temperature

Additional facilities recommended

$1 \mathrm{MRI} / \mathrm{MRA}$

2 Diffusion and perfusion MR

3 CTA

4 ECG (transoesophageal)

5 Cerebral angiography

6 Transcranial Doppler sonography

7 Specialised neuroradiological, neurosurgical and vascular surgical consultation

ment of stroke subtypes based on the physical and neurological evaluation as well as on skilled interpretation of the results of $\mathrm{CT}$ and magnetic resonance imaging (MRI) scanning is essential for the prediction of a high risk of early recurrence.

The initial examination includes observation of breathing and pulmonary function, concomitant heart disease, assessment of blood pressure and heart rate, and determination of arterial oxygen saturation using infrared pulse oxymetry if available. Simultaneously, blood samples for clinical chemistry, coagulation and haematology studies are drawn, and a venous line is inserted. Standard electrolyte solutions are given until clinical chemistry results are available. After the emergency assessment, which in part will be done by emergency nurses or other emergency room personnel, the neurologist should perform a targeted neurological examination. The examination is supplemented, if possible, by a careful medical history focussing on risk factors for ateriosclerosis and cardiac disease. Especially in young patients, a history of drug abuse, oral contraceptive use, infection, trauma or migraine may give important clues (table 3 ).

European Stroke Initiative

Recommendations for Stroke Management
Table 3. Emergent diagnostic tests in acute stroke

\section{$1 \mathrm{CT}$}

2 ECG and chest X-ray

3 Clinical chemistry

Complete blood count and platelet count, prothrombin time, INR, PTT

Serum electrolytes, blood glucose

CRP, sedimentation rate

Arterial blood gas analysis, if hypoxia is suspected

Hepatic and renal chemical analyses

4 Pulse oxymetry

5 Lumbar puncture (only if CT is negative, CT and subarachnoidal haemorrhage is clinically suspected)

6 Duplex and transcranial ultrasound

7 EEG $^{1}$

$8 \mathrm{MRI}^{1}$ and $\mathrm{MRA}^{1} / \mathrm{CTA}^{1}$

9 Diffusion $\mathrm{MR}^{1}$ and perfusion $\mathrm{MR}^{1}$

10 ECG (transthoracic and transoesophageal)*

PTT $=$ Partial thrombin time; $\mathrm{CRP}=\mathrm{C}$-reactive protein .

1 In selected cases.

\section{Diagnostic Imaging}

Cranial CT is widely available and not only reliably distinguishes between haemorrhage and ischaemic stroke or subarachnoid haemorrhage, but can also rule out many other brain diseases. Signs of early ischaemia can sometimes be detected as early as $2 \mathrm{~h}$ after stroke onset, but this may be difficult even for the trained examiner, in particular in very early studies. Early infarct signs include sulcus effacement, swelling of the basal ganglia and the hyperintense middle cerebral artery (MCA) sign. Early signs of extensive infarction with intracranial midline shifts indicate a very serious event and a high risk both for secondary haemorrhage and large malignant oedema formation and may justify repeated imaging after a short interval.

Parenchymal haemorrhage can be identified almost immediately either in deep structures in patients with hypertension or in atypical areas in patients without hypertension or under adequate treatment, usually due to cerebral amyloid angiopathy. Infratentorial haemorrhage or cerebellar infarcts can be identified similar to supratentorial lesions, but smaller haemorrhages/ischaemic infarcts, in particular in the brain stem, may easily be missed. In addition, CT may detect subarachnoid blood in the majority of cases with subarachnoid haemorrhage. Sometimes haemorrhages may even be interpreted as primary, but indeed are secondary to ischaemic events. Involvement of clearly defined vascular territories are indicative of such conditions, which are easier to identify in MRI studies. Brain haemorrhages tend to grow in the first 6-12 $\mathrm{h}$ after stroke

Cerebrovasc Dis 2003;16:311-337 
in about $40-50 \%$ of all patients even without clinical deterioration, which makes a second early CT study necessary. CT angiography (CTA) is a reliable tool to obtain information on extracranial and intracranial arterial patency, and its use in clinical practice often adds value to the diagnostic work-up [Schellinger et al., 2003].

MRI is more sensitive and is increasingly used in referral hospitals with stroke unit expertise as a standard procedure. Recent objections because of a suspected lower sensitivity to identify brain haemorrhages have been overcome by modern MRI techniques such as $\mathrm{T}_{2}$-weighted imaging, which indeed are even more sensitive than CT scanning for the display of intracerebral haemorrhage. Diffusionweighted MR is very sensitive for early detection of the damaged brain tissue and combined with perfusionweighted MR may help identify patients who benefit from early thrombolysis. In fact, current concepts suggest that patients with a significant perfusion-diffusion mismatch may benefit from restoration of the ischaemic penumbra surrounding an already necrotic core of infarction, whereas those with overlapping areas of diffusion and perfusion deficits have a less favourable benefit/risk ratio. These MR techniques are not yet available on a large scale, but do seem promising tools for future routine applications. MR angiography (MRA) can be used to identify occlusions of major intracranial arteries but should carefully be interpreted if studies from extracranial cerebral arteries are missing. In this case, ultrasound can be useful to identify severe haemodynamical relevant carotid obstructions, which are likely to produce significant perfusion deficits in small embolic or lacunar strokes and may thus mimic falsely a remarkable perfusion-diffusion mismatch. MRA also has a role in evaluating the venous system and aneurysms down to a 3-mm diameter.

Ultrasound studies are routinely performed in stroke centres. The major goal is to identify large obstructive lesions in the extracranial as well as in the intracranial basal arteries. In addition, transcranial Doppler may be useful to monitor spontaneous or drug-induced thrombolysis in the majority of patients. In about one quarter of the patients, it is not possible or very difficult to get adequate signals through the temporal bone window without application of contrast agents. The detection of rare causes of ischaemic stroke, such as dissections, intimal hyperplasia and other less frequent aetiologies is facilitated by the systematic use of ultrasound studies. Transoesophageal and transthoracic echocardiography (ECG) is frequently indicated in suspected cardio-embolic stroke but usually not performed on an emergency basis. It seems useful to have these studies available within the first $24 \mathrm{~h}$ after onset of stroke to choose the best available secondary prevention, in particular in the presence of cardiac sources of embolism. They can also sometimes be identified by means of MCA monitoring if high intensity transient signals are observed.

\section{Recommendations}

1 A head CT is the most important diagnostic tool in patients with suspected stroke to differentiate between ischaemia and haemorrhage.

2 Vascular imaging (ultrasound, CTA and MRA) in the acute condition gives additional information about the vessel patency in the brain and neck vessels and should supplement all imaging procedures already in the acute phase.

$3 \mathrm{MRI} / \mathrm{MRA}$ can replace CT if performed appropriately and in particular $\mathrm{T}_{2}$-weighted imaging is necessary to identify even small haemorrhages.

4 Diffusion and perfusion MR may be of additional help for assessing the risk/benefit ratio for early revascularization therapy.

5 Early evaluation of physiological parameters, blood chemistry and haematology, and cardiac function (ECG, pulse oxymetry, chest X-ray) is recommended in the management of acute stroke patients (level IV).

\section{Quality Management and Control of Process Quality}

It is mandatory to establish a documentation system for all strokes in a way that allows evaluation of major characteristics of the patients treated in stroke units. Items chosen must also allow case mix analyses across units, regions or even countries. These should include major predictors of outcome such as age, NIH scale values at onset and diabetes. Several systems of documentations have been developed and recommended for use. It is important to help young colleagues understand that such documentation has to be performed concurrently by either the treating physicians or the stroke nurses themselves and should not be left to additional staff that otherwise do not participate in the work of the stroke unit. It is essential to have follow-up data at least 3 months following the stroke onset in order to enable benchmarking. These data should at least include mortality and Rankin scale. In addition, process quality should also be monitored and evaluated on a regular basis. Some recommendations are listed in table 4.

\section{Rehabilitation}

Forty per cent of stroke patients need active rehabilitation services. Rehabilitation of a stroke victim is started as soon as he/she is clinically stable. The intensity of the 
actual rehabilitation programme depends on the status of the patient and the degree of the disability. In patients incapable of active training, passive methods may be used to prevent contractions and joint pain and to prevent distress for the patient when active movement is possible. Passive rehabilitation measures also minimise the risk of bedsores and pneumonia. All joints on the paralysed side are moved through the full range of motion several times a day (3-4 times at least). Co-operative patients are encouraged to take an active part in the rehabilitation programme. Prolonged immobilisation and hemiplegia carry the risk of deep venous thrombosis and pulmonary embolism.

Treatment in dedicated stroke rehabilitation wards is based on multidisciplinary teamwork consisting of a physician, physiotherapist, speech therapist, occupational therapist, neuropsychologist, social worker and a nurse [Stroke Unit Trialists' Collaboration, 2002]. In such a unit, there is a motivating and encouraging attitude that maintains the patient's desire to improve. Important is a milieu of an 'enriched environment', where patients feel comfortable, and which supports the patient's efforts and encourages him/her to practise even beyond working hours [Johansson, 2000]. Elderly stroke patients may equally benefit from the well-organised management of stroke [Kaste et al., 1995; Jørgensen et al., 2000].

As soon as the patient is stable, he/she should be carefully assessed for the degree of disability. The extent and distribution of motor weakness and the accompanying sensory and proprioceptive deficits should be noted in detail. The assessment should include evaluation of intellectual impairment, especially specific cognitive deficits such as aphasia, apraxia, agnosia, disorders of memory and attention, and the broad range of emotional distress and motivational disturbances. When the patient is transferred to a rehabilitation hospital, it is of the utmost importance that all members of the stroke team transfer documentation of the patient's progress to the stroke team of the rehabilitation hospital [Kaste et al., 1995]. After institutional rehabilitation, the rehabilitation programme can be taken over by an out-patient rehabilitation clinic. This ensures the smooth transfer of the patient to the next rehabilitation step back to normal. The length of the rehabilitation period in the acute stage depends upon the severity of the stroke and locally available stroke rehabilitation services. Under usual circumstances, rehabilitation following the acute phase of ischaemic stroke should not last longer than 6-12 weeks and rarely more than 24 weeks.

Recent reports of rehabilitation methods that are based on developing muscle strength and increasing the width of movements with plentiful repetition and en-
Table 4. Recommendations for the quality control of time frames for treatment of acute stroke

\begin{tabular}{|c|c|}
\hline Time frame prolonged & Recommendation \\
\hline $\begin{array}{l}\text { Time from stroke onset to } \\
\text { calling emergency service }\end{array}$ & $\begin{array}{l}\text { Increase public information and } \\
\text { support stroke awareness } \\
\text { campaigns }\end{array}$ \\
\hline $\begin{array}{l}\text { Time from stroke onset to } \\
\text { hospital door }\end{array}$ & Training of paramedics necessary \\
\hline Time from hospital door to CT & $\begin{array}{l}\text { Screening and revision of } \\
\text { intra-hospital organisation }\end{array}$ \\
\hline
\end{tabular}

hanced resistance training of the affected limb are called 'forced use'. Novel restorative programmes that focus on the functional improvement of the upper extremity [Duncan, 1997; Taub et al., 1993; Miltner et al., 1999] or on the recovery of gait [Hesse et al., 2001; Werner et al., 2002] have provided promising tools for the treatment of stroke patients with residual disability.

The fastest recovery of neurological deficit occurs during the first 3 months after the onset of symptoms. Active rehabilitation, however, should be administered as long as objective improvement in the neurological function is observed.

In addition to national organisations involved in providing information to stroke survivors, the role of locally based self-help groups is important in supporting stroke patients and their caregivers. Well-integrated social and medical care with case management programmes may be one way to reduce admission to institutions and prevent functional decline in the elderly [Bernabei et al., 1998]. Supporting the patient in his/her social environment is important. Keeping up social contacts is perhaps something that offers the best opportunity to influence the patient's quality of life. Every chronic stroke patient with a marked disability should have regular contact with a family physician, who can encourage the patient, notice possible impairment of clinical state, and take care of secondary prevention.

With focused rehabilitation programmes, stroke patients can become ambulatory and largely independent. Of major importance is that the majority of survivors are able to live at home and do not require nursing home care [Kramer et al., 1997]. That such results can be achieved with systematic stroke management - and not by chance is verified by identical results from University Hospitals of Umeå, Sweden [Strand et al., 1985], Copenhagen, Denmark, Kuopio, Finland [Sivenius et al., 1985] and Trondheim, Norway [Indredavik et al., 1991]. 
Recommendations

1 Every patient should have access to evaluation for rehabilitation.

2 In patients with a clear indication for rehabilitation, treatment should be initiated early after stroke (level I). Disabled patients should have access to structured care including institutional care.

3 Rehabilitation should be provided by a multidisciplinary team in a stroke unit (level I).

4 Intensity and duration of rehabilitation should be optimal for each patient; new methods of rehabilitation should be used (e.g. repetitive training and forced use), ideally supplementary to established methods (II).

5 Patients with chronic symptomatic stroke should be supported in their social environment. This includes access to a family physician, evaluation of out-patient rehabilitation services, secondary prevention and support in psychosocial functioning (level II).

\section{Prevention}

\section{Primary Prevention}

Primary prevention aims to reduce the risk of stroke in asymptomatic people. Recommendations concerning patients with TIAs are considered here as secondary prevention. Relative risk reduction (RRR), absolute risk reduction (ARR) and NNT to avoid 1 major vascular event per year are provided for each therapy in tables 5, 6 , and 7 .

\section{Arterial Hypertension (High Blood Pressure)}

Elevated blood pressure is strongly and directly related to vascular and overall mortality without any evidence of a threshold [Lewington et al., 2002]. Lowering high blood pressure substantially reduces this risk, depending on the magnitude by which blood pressure is lowered [Neal et al., 2000; Staessen et al., 2001]. Most studies comparing different drugs have not suggested that any class is superior [Neal et al., 2000; Staessen et al., 2001], except losartan (50-100 mg) vs. atenolol [Dahlof et al., 2002] and chlorthalidone vs. amlodipine and lisinopril [ALLHAT Investigators, 2002].

\section{Diabetes mellitus}

Since there are other good reasons to treat diabetes appropriately, it seems prudent to do so in those at risk for stroke. Blood pressure should be lowered more aggressively in diabetics to achieve levels below $135 / 80 \mathrm{~mm} \mathrm{Hg}$ [Turner et al., 1999].
Table 5. RRR, ARR and NNT to avoid 1 stroke per year in patients who undergo surgery for ICA stenosis (modified from Hankey and Warlow [1999])

\begin{tabular}{llll}
\hline Disease & $\begin{array}{l}\text { RRR } \\
\%\end{array}$ & $\begin{array}{l}\text { ARR/year } \\
\%\end{array}$ & $\begin{array}{l}\text { NNT to avoid } \\
1 \text { stroke/year }\end{array}$ \\
\hline Asymptomatic (60-99\%) & 53 & 1.2 & 85 \\
Symptomatic (70-99\%) & 65 & 3.8 & 27 \\
$\begin{array}{l}\text { Symptomatic (50-69\%) } \\
\text { Symptomatic (<50\%) }\end{array}$ & $\begin{array}{l}29 \\
\text { no benefit }\end{array}$ & $\begin{array}{l}1.3 \\
\text { no benefit }\end{array}$ & $\begin{array}{l}75 \\
\text { no benefit }\end{array}$ \\
\hline
\end{tabular}

The American Diabetes Association recommends using aspirin in primary prevention for anyone with diabetes older than 30 years with no known contra-indications [American Diabetes Association, 2000].

\section{Hyperlipidaemia}

Three primary or combined primary/secondary prevention trials were unable to show a significant reduction in stroke rate under pravastatin [ALLHAT Investigators, 2002; West of Scotland Coronary Prevention Study Group, 1998; Shepherd et al., 2002], despite a tendency (minus 11\%) in men [WOSCOP Study Group, 1998]. In the larger Heart Protection Study [2002], the reduction in the event rate under simvastatin was significant even in those with low-density lipoprotein cholesterol below $3.0 \mathrm{mmol} / 1(116 \mathrm{mg} / \mathrm{dl})$ or total cholesterol below $5.0 \mathrm{mmol} / 1(193 \mathrm{mg} / \mathrm{dl})$. The annual excess of myopathies was 1 per 10,000 patients treated [Heart Protection Study, 2002].

\section{Cigarette Smoking}

Cohort studies have shown cigarette smoking to be an independent risk factor for ischaemic stroke [Wolf et al., 1988] in men [Abbott et al., 1986] and women [Colditz et al., 1988]. A meta-analysis of 22 studies indicates that smoking doubles the risk of ischaemic stroke [Shinton et al., 1989]. Subjects who stop smoking reduce this risk by $50 \%$ [Colditz et al., 1988].

\section{Alcohol Consumption}

Heavy alcohol drinking (more than $60 \mathrm{~g} /$ day) increases the risk of stroke, while light or moderate alcohol consumption may be protective against all strokes and ischaemic strokes. Consumption of up to $12 \mathrm{~g}$ of alcohol per day was associated with an RRR of all strokes (RR: 0.83) and of ischaemic stroke (RR: 0.80). Moderate consumption (12-24 g/day) was associated with a reduced risk of ischaemic stroke (RR: 0.72) [Reynolds et al., 2003]. 
Table 6. RRR, ARR and NNT to avoid 1 major vascular event per year in patients with antithrombotic therapy (modified from Hankey and Warlow [1999])

\begin{tabular}{lllll}
\hline Disease & Treatment & $\begin{array}{l}\text { RRR } \\
\%\end{array}$ & $\begin{array}{l}\text { ARR/year } \\
\%\end{array}$ & $\begin{array}{l}\text { NNT to avoid } \\
\text { 1 major vascular } \\
\text { event/year }\end{array}$ \\
\hline Non-cardio-embolic & ASA/placebo & 13 & 1.0 & 100 \\
ischaemic stroke or TIA & ASA + DIP/aspirin & 15 & 0.9 & 111 \\
& ASA + DIP/placebo & 19 & 1.2 & 53 \\
& clopidogrel/ASA & 13 & 0.6 & 166 \\
AF (primary prevention) & warfarin/placebo & 62 & 2.7 & 37 \\
& ASA/placebo & 22 & 1.5 & 67 \\
AF (secondary prevention) & warfarin/placebo & 67 & 8 & 13 \\
& ASA/placebo & 21 & 2.5 & 40 \\
& & & &
\end{tabular}

ASA $=$ Aspirin; DIP $=$ dipyridamol.

Table 7. RRR, ARR and NNT to avoid 1 major vascular event per year in patients with risk factors modification (modified from Hankey and Warlow [1999])

\begin{tabular}{lllll}
\hline Clinical condition & Treatment & $\begin{array}{l}\text { RRR } \\
\%\end{array}$ & $\begin{array}{l}\text { ARR } \\
\%\end{array}$ & $\begin{array}{l}\text { NNT to avoid } \\
\text { 1 stroke/year }\end{array}$ \\
\hline General population with increased blood pressure & antihypertensive & 42 & 0.2 & 94 \\
Post-stroke/TIA with increased blood pressure & antihypertensive & 31 & 2.2 & 45 \\
Post-stroke/TIA with normal blood pressure & antihypertensive & 28 & 4 & 42 \\
Post-stroke/TIA & statins & 24 & 1.7 & 59 \\
& smoking cessation & 33 & 2.3 & 43 \\
\hline
\end{tabular}

\section{Lifestyle Modification}

In men, vigorous exercise was associated with a decreased risk of stroke [Lee et al., 1999]. The data suggested that this association was mediated through beneficial effects on body weight, blood pressure, serum cholesterol and glucose tolerance, and that, apart from these effects, physical activity had no influence on stroke incidence. Substantial evidence supports the use of diets high in nonhydrogenated unsaturated fats, whole grains, fruit and vegetables, fish once a month and adequate $n-3$ fatty acids to reduce the risk of ischaemic heart disease and probably stroke [Hu and Willett, 2002; He et al., 2002].

\section{Postmenopausal Oestrogen Replacement Therapy}

Stroke rates rise rapidly in women once they become menopausal. However, in an analysis based on a 16-year follow-up of 59,337 postmenopausal women participating in the Nurses' Health Study, there was only a weak association between stroke and oestrogen replacement [Grodstein et al., 2001]. According to the HERS II trial, hormone replacement in healthy women is associated with an increased risk of ischaemic stroke [Grady et al., 2002].

\section{Recommendations}

1 Blood pressure measurement is an essential component of regular health care visits. Blood pressure should be lowered to normal levels $(<140 /<90 \mathrm{~mm} \mathrm{Hg}$, or $<135 / 80 \mathrm{~mm} \mathrm{Hg}$ in diabetics) by means of lifestyle modification. Most hypertensive patients will also need pharmacological treatment to achieve normal blood pressure (level I).

2 Although strict control of glucose levels in diabetes mellitus has not been proven to be associated with a decreased risk of stroke, it should be encouraged because of benefits in terms of other diabetic complications (level III).

3 Cholesterol-lowering therapy (simvastatin) is recommended for high-risk patients (level I).

4 Cigarette smoking should be discouraged (level II).

5 Heavy use of alcohol should be discouraged, light or moderate alcohol consumption may be protective against stroke (level I).

6 Regular physical activity is recommended (level II).

7 A low salt, low saturated fat, high fruit and vegetable diet rich in fibre is recommended (level II).

8 Subjects with an elevated body mass index should take a weightreducing diet (level II).

9 Hormone replacement therapy (oestrogen/progesterol) should not be used for primary prevention of stroke (level I). 


\section{Antithrombotic Therapy}

A meta-analysis [Hart et al., 2000] of the 5 trials [Peto et al., 1988; Steering Committee of the Physicians Health Study Research Group, 1989; EDTRS Investigators, 1992; Hansson et al., 1998; Meade, 1998] comparing aspirin with no aspirin in 52,251 subrin with no aspirin in 52,251 subjects after a mean follow-up of 4.6 years found no effect on stroke rate. A further trial found that aspirin (100 mg per day) was associated with a non-significant reduction in stroke of $33 \%$ [de Gaetano, 2001]. No data are available on the use of other antiplatelet agents in primary prevention. There is no proof that aspirin is beneficial in patients with asymptomatic internal artery stenosis, but these patients being at increased risk for MI, there is a consensus to use aspirin.

Warfarin reduces the rate of ischaemic stroke by $70 \%$ in patients with atrial fibrillation (AF), with an optimal international normalised ratio (INR) level between 2.0 and 3.0 [The European Atrial Fibrillation Study Group, 1995]. In this group, aspirin ( $300 \mathrm{mg}$ per day) reduces stroke by $21 \%$ and is significantly less efficacious than warfarin [Hart et al., 1998]. As the annual rate of stroke among people with AF is very wide, risk stratification should be used to determine whether patients should be given oral anticoagulation, aspirin or nothing [Fuster et al., 2001]. Oral anticoagulation has a higher chance to be effective in patients with $\mathrm{AF}$ who have one or more risk factors, such as a previous ischaemic stroke, TIA or a previous systemic embolism, age over 75 years, high blood pressure or poor left ventricular function [Fuster et al., 2001]. In patients over 75 years, warfarin used with high INR values (range 3.0-4.5) increase the risk of haemorrhage [The Stroke Prevention in Reversible Ischemia Trial Study Group, 1997]. Patients with AF who have prosthetic heart valves should receive long-term anticoagulation with a target INR based on the prosthesis type, but not less than INR 2-3 [Fuster et al., 2001].

Recommendations

1 Although aspirin does not reduce the risk of stroke in healthy subjects, it does reduce the risk of MI and can be recommended in subjects with one or more vascular risk factors (level I).

2 Clopidogrel, ticlopidine, trifusal and dipyridamole have not been studied in asymptomatic subjects and therefore cannot be recommended for primary stroke prevention (level IV).

3 Asymptomatic patients with a greater than $50 \%$ internal carotid artery (ICA) stenosis should receive aspirin in order to reduce the risk of MI (level IV).

4 Long-term oral anticoagulation therapy (target INR 2.5; range 2.0-3.0) should be considered for all AF patients at high risk of embolism: age $>75$ years, or age $>60$ years plus risk factors such as high blood pressure, left ventricular dysfunction, and diabetes mellitus (level I).

5 Long-term aspirin (325 mg per day) or warfarin are recommended for patients with non-valvular $\mathrm{AF}$ at moderate risk of embolism: age 60-75 years without additional risk factors level I).

6 Warfarin is recommended for AF patients aged 60-75 with diabetes or coronary heart disease (level I).

7 Although not yet established by randomised studies, in patients over 75 years, warfarin may be used with a lower INR (target INR of 2.0; range 1.6-2.5) to decrease the risk of haemorrhage (level III).

8 Patients with AF unable to receive oral anticoagulants should be offered aspirin (level I).

9 Long-term aspirin (325 mg per day) or no therapy are recommended for patients with non-valvular AF at low risk of embolism: age $<60$ years without additional risk factors (level I).

10 Patients with AF who have prosthetic heart valves should receive long-term anticoagulation with a target INR based on the prosthesis type, but not less than INR 2-3 (level II).

\section{Carotid Surgery and Endovascular Treatment for Asymptomatic Carotid Stenosis}

The Asymptomatic Carotid Atherosclerosis Study reported that patients with an asymptomatic carotid stenosis greater than $60 \%$ had a 5 -year RRR of $53 \%$ of ipsilateral stroke if carotid surgery was performed [Executive Committee for the Asymptomatic Carotid Atherosclerosis Study, 1995]. However, the ARR was small (5.9\% in 5 years), as was the rate of ipsilateral stroke in the medically treated group ( $11.0 \%$ in 5 years, or $2.3 \%$ annually). Moreover, these results were achieved with a perioperative rate of complications (stroke or death) of only $2.3 \%$. A metaanalysis of 5 trials of carotid surgery for asymptomatic carotid stenosis concluded that, although surgery reduces the incidence of ipsilateral stroke, the absolute benefit of carotid surgery is small, as the rate of stroke in medically treated patients is low [Benavente et al., 1998]. Medical management alone is the best alternative for many asymptomatic subjects.

Specific Issues. (1) Patients with an occlusion of the ICA contralateral to the operated carotid artery do not benefit from endarterectomy [Baker et al., 2000; Straus et al., 2002]. (2) The ipsilateral stroke risk increases with the degree of the stenosis [The European Carotid Surgery Trialists Collaborative Group, 1995; Inzitari et al., 2000]. (3) A subgroup analysis of the Asymptomatic Carotid Atherosclerosis Study indicates that women have significantly lower benefit from surgery than men. (4) There are no prospective trials investigating the benefit of antiplatelet drugs in patients with asymptomatic carotid stenosis [Chambers et al., 2002]. 


\section{Carotid Artery Angioplasty and Stenting for} Asymptomatic Stenosis

There are no data from randomised trials about the benefit and risk of carotid angioplasty compared with endarterectomy in asymptomatic patients [Roubin et al., 2001].

\section{Recommendations}

1 Carotid surgery may be indicated for some asymptomatic patients with a $60-99 \%$ stenosis of the ICA. The carotid endarterectomy (CEA)-related risk of stroke or death must be less than 3\%, and patients with a life expectancy of at least 5 years (or under the age of 80) may benefit from surgery (level II).

2 Carotid angioplasty, with or without stenting, is not routinely recommended for patients with asymptomatic carotid stenosis. It may be considered in the context of randomised clinical trials.

\section{Secondary Prevention}

\section{Antiplatelet Therapy}

A meta-analysis of 287 trials [Antiplatelet Trialists Collaboration, 2002] showed a $25 \%$ relative reduction of serious vascular events (non-fatal myocardial infarction, nonfatal stroke or vascular death) under antiplatelet therapy in patients with previous ischaemic stroke or TIA: when 1,000 patients are treated for 2 years, 36 events are prevented among those with previous stroke or TIA, and this benefit substantially outweighs the absolute risks of major extracranial bleeding [Antiplatelet Trialists Cooperation, 2002]. Another meta-analysis has attributed a more modest 13\% RRR under antiplatelet therapy [Algra et al., 2000].

Aspirin. Studies directly comparing the effects of different doses of aspirin failed to show differences in stroke recurrences [Algra and van Gijn, 1996; The Dutch TIA Study Group, 1991; Farrell et al., 1991]. The risk/benefit ratio of adding another antithrombotic drug to aspirin has not been fully studied.

Clopidogrel. Clopidogrel is slightly more effective than aspirin in preventing vascular events [CAPRIE Steering Committee, 1996]. It is the agent of choice in patients with contra-indications, or adverse effects, to aspirin and may be more effective in higher risk patients (i.e. with a previous stroke, peripheral artery disease, symptomatic coronary disease and diabetes) and after coronary surgery [Bhatt et al., 2000].

Dipyridamole Plus Aspirin. The ESPS II Study [Diener et al., 1996], a randomised, double-blind, placebo-controlled trial, showed that the combination of aspirin $(50 \mathrm{mg})$ plus dipyridamole $(400 \mathrm{mg})$ doubles the effect of aspirin alone and of dipyridamole alone: the RRR versus placebo were 37,18 and $16 \%$, respectively.

Specific Issues. (1) The incidence of major bleeding complications is independent of the dose of aspirin. (2) The incidence of gastro-intestinal disturbances with aspirin is dose dependent. Lower doses are safer. (3) The treatment of patients who have a recurrent vascular event on antithrombotic therapy remains unsettled. Such patients should be re-evaluated for pathophysiology and risk factors. Patients without cardiac sources of embolism who suffered a recurrent event while under aspirin do not benefit from warfarin.

\section{Recommendations}

1 Appropriate antiplatelet therapy should be given to prevent stroke recurrence and further vascular events (level I). There are three treatment options that may all be considered as first choice depending on patient characteristics.

2 Aspirin 50-325 mg should be given to reduce stroke recurrence (level I).

3 Where available, the combination of aspirin $(50 \mathrm{mg})$ and long release dipyridamole (200 mg twice daily) can be given as first choice to reduce the risk of stroke recurrence (level I).

4 Clopidogrel is slightly more effective than aspirin in the prevention of further vascular events (level I).

5 It may also be prescribed as first choice or when aspirin and dipyridamole are not tolerated (level IV), and in high-risk patients (level III).

6 Patients with TIA or ischaemic stroke and unstable angina or non-Q-wave MI should be treated with a combination of clopidogrel $75 \mathrm{mg}$ and aspirin $75 \mathrm{mg}$ (level III).

7 Patients starting treatment with thienopyridine derivatives should receive clopidogrel instead of ticlopidine because it has fewer side-effects (level III).

8 In patients who cannot be treated by aspirin or thienopyridine derivatives, long release dipyridamole alone (200 mg twice daily) may be used as an alternative (level II).

\section{Anticoagulation}

Oral anticoagulation (INR 2.0-3.0) reduces the risk of recurrent stroke in patients with non-valvular AF and recent ischaemic stroke [The European Atrial Fibrillation Study Group, 1995; Fuster et al., 2001].

Although evidence from randomised trials is lacking, long-term anticoagulation is routinely used for patients with mechanical prosthetic valves, with a target INR between 3.0 and 4.0 [Cannegieter et al., 1995]. There is no argument supporting oral anticoagulation in non-cardiac ischaemic strokes [Mohr et al., 2001], and an excessive mortality and major bleeding in excessively anticoagulated patients (target INR 3.0-4.5) was even found in the Stroke 
Prevention in Reversible Ischemia Trial [The Stroke Prevention in Reversible Ischemia Trial Study Group, 1997].

Specific Issues. (1) Some retrospective studies suggest that anticoagulation may be beneficial in specific circumstances: aortic atheroma [Dressler et al., 1998], fusiform aneurysms of the basilar artery [Echiverri et al., 1989] or arterial dissection. There are no consistent data relating to anticoagulation after cervical artery dissection. (2) Oral anticoagulation should probably be avoided in elderly patients with leucoaraiosis [The Stroke Prevention in Reversible Ischemia Trial Study Group, 1997]. (3) It is unclear if patients with patent foramen ovale benefit from oral anticoagulation. Patients without proven deep vein thrombosis (DVT) or associated atrial septal aneurysm should probably be given aspirin. The roles of anticoagulation and closure of the patent foramen ovale remain to be elucidated [Mas et al., 2001].

\section{Recommendations}

1 Oral anticoagulation (INR 2.0-3.0) is indicated after ischaemic stroke associated with AF (level I). Oral anticoagulation is not advisable in patients with comorbid conditions such as falls, epilepsy, severe dementia, or gastro-intestinal bleedings.

2 Patients with prosthetic heart valves should receive long-term anticoagulation therapy with a target INR between 2.5 and 3.5 or higher (level II).

3 Patients with proven cardio-embolic stroke should be anticoagulated, if the risk of recurrence is high, with a target INR between 2.0 and 3.0 (level III).

4 Anticoagulation should not be used after non-cardio-embolic ischaemic stroke, except in some specific situations, such as aortic atheromas, fusiform aneurysms of the basilar artery or cervical artery dissection (level IV).

\section{Antihypertensive Treatment}

A meta-analysis from 9 randomised controlled trials on antihypertensive drugs, in which a small number of stroke survivors had been included, led to an estimated RRR for stroke of 29\% (95\% CI: 5-47) [The INDIANA Project Collaborators, 1997]. Indapamide (2.5 mg daily), a diuretic, reduces the risk of recurrent stroke by $29 \%$ (absolute reduction $2.9 \%$ ) after 3 years, in patients with high blood pressure and recent stroke or TIA [PATS Collaborating Group, 1995]. The HOPE Study showed an effective prevention of secondary ischaemic events by an ACE inhibitor (ramipril) in high-risk patients including those who had already had a stroke [Yusuf et al., 2000], despite a modest reduction in blood pressure. The PROGRESS trial showed that patients who had had a stroke or TIA within 5 years and received perindopril (4 mg daily) plus indapamide (2-2.5 mg daily) had a significant $43 \%$ reduction in the risk of recurrent stroke [PROGRESS Collaborative Group, 2001]. This benefit was achieved regardless of blood pressure and type of stroke [PROGRESS Collaborative Group, 2001].

Specific Issues. (1) Although there is no convincing evidence, patients at risk of haemodynamic stroke as a consequence of occlusive or severe stenotic disease of the carotid or vertebrobasilar arteries, or who have cardiac failure, should not have their blood pressure lowered excessively. (2) ACE inhibitors may be considered in patients with haemodynamic brain compromise because they shift the autoregulation curve of the cerebral blood flow towards normal values.

\section{Recommendations}

1 After stroke or TIA, blood pressure should be lowered, irrespective of its level, with a diuretic and/or an ACE inhibitor, subject to toleration of the treatment (level I).

2 The effectiveness of other classes of blood pressure-lowering drugs has not yet been established by controlled trials.

\section{Cholesterol-Lowering Therapy}

A significant reduction in stroke risk is seen across all treatment groups [Di Mascio et al., 2000]. Most of this effect was driven by trials involving patients with a prior vascular event using a statin, or where a reduction in total cholesterol levels of more than 10\% was achieved. In secondary prevention, 57 patients would need to be treated with statins to prevent 1 stroke per year [Straus et al., 2002]. The MRC/BHF Heart Protection Study had a subgroup of 1,820 patients with previous stroke or TIA and no previous coronary event: simvastatin ( $40 \mathrm{mg}$ daily) reduced the risk of recurrent vascular events by $24 \%$ [Heart Protection Study Collaborative Group, 2002]. The PROSPER trial showed that a similar reduction in the risk of coronary events was observed under pravastatin in older individuals, without significant effect on stroke or cognition after 3 years of follow-up [Sheperd et al., 2002]. Gemfibrozil, a fibrate, can also reduce the risk of stroke [Rubins et al., 1999].

\section{Recommendation}

1 Patients with a history of ischaemic stroke or TIA should be considered for statin (simvastatin) therapy (level I). 


\section{Hormone Replacement Therapy}

In the Women's Oestrogen for Stroke Trial, a placebocontrolled randomised trial of oestrogen replacement therapy for the secondary prevention of ischaemic stroke, the risk of fatal stroke was higher (not significant) with oestrogens, and non-fatal strokes were associated with worse functional outcomes [Viscoli et al., 2001].

\section{Recommendation}

1 There is no indication to use hormone replacement therapy for secondary stroke prevention in postmenopausal women (level II).

\section{Smoking}

Smoking cessation leads to an early reduction in risk of both coronary events and stroke at any age [Kawachi et al., 1993; Wannamethee et al., 1995; Colditz et al., 1988].

Recommendation

1 All smokers should stop smoking, especially patients who have had stroke (level IV).

\section{Carotid Endarterectomy}

The North American Symptomatic Carotid Endarterectomy Trial (NASCET) [North American Symptomatic Carotid Endarterectomy Trial Collaborators, 1991] and the European Carotid Surgery Trialists Collaborative Group [European Carotid Surgery Trialists Collaborative Group, 1995] reported that surgery was efficacious for symptomatic patients with ipsilateral carotid stenosis greater than $70 \%$. Although these trials used different methods of measurement, it is possible to predict the percentage of stenosis from one method to another, and there is little difference in their ability to predict ipsilateral stroke [Rothwell et al., 2003]. The NASCET analysis of surgery for symptomatic patients with less than $70 \%$ stenosis revealed an ARR of $6.5 \%$ and an RRR of $29 \%$ for patients with 50-69\% stenosis allocated for surgery [Barnett et al., 1998]; the overall significance of carotid surgery in preventing ipsilateral stroke was marginal $(\mathrm{p}=$ 0.045 ) and the CIs overlapped in the survival curves.

Specific Issues. (1) Elderly patients ( $>75$ years) without organ failure or serious cardiac dysfunction benefit from CEA. (2) Women with symptomatic stenosis $>70 \%$ should undergo CEA. Women with moderate stenosis should be treated medically. (3) Patients with few risk factors who present with amaurosis fugax only are better off with medical treatment. Patients with severe stenosis and high risk profile should be considered for CEA. (4) Patients with mild to moderate intracranial stenosis and severe extracranial stenosis are ideal candidates for CEA. (5) The benefit from CEA is lower for patients with lacunar stroke. (6) Patients with leucoaraiosis should be made aware of the increased operative risk. (7) Occlusion of the contralateral ICA is not a contra-indication to CEA but carries a higher perioperative risk. (8) Continuation of aspirin is required until surgery, but heparin may be used in very severe stenosis. (9) The benefit from endarterectomy is marginal in patients with carotid near-occlusion. (10) All grading of stenoses should be according to NASCET criteria.

\section{Recommendations}

1 Conventional angiography, or one or ideally more of the following investigations - ultrasonography, MRA, or CTA - may be used to identify and quantify carotid artery stenosis.

2 CEA is indicated for patients with stenosis of $70-99 \%$ without a severe neurological deficit with recent $(<180$ days $)$ ischaemic events. This is valid only for centres with a perioperative complication rate (all strokes and death) of less than $6 \%$ (level I).

3 CEA may be indicated for certain patients with stenosis of 50 $69 \%$ without a severe neurological deficit. This is valid only for centres with a perioperative complication rate (all strokes and death) of less than $6 \%$. The subgroup of patients most likely to benefit from surgery is males with recent hemispheric symptoms (level III).

4 CEA is not recommended for patients with stenosis of less than $50 \%$ (level I).

5 CEA should not be performed in centres not exhibiting low complication rates similar to those seen in NASCET or the European Carotid Surgery Trialists Collaborative Group (level I).

6 Patients should remain on antithrombotic therapy before, during and after surgery (level II).

7 Patients should be followed up by the referring physician as well as the surgeon (level IV).

\section{Extracranial-Intracranial Anastomosis}

Anastomosis between the superficial temporal and middle cerebral arteries is not beneficial in preventing stroke in patients with MCA or ICA stenosis or occlusion [The EC/IC Bypass Study Group, 1985].

\section{Carotid Angioplasty and Stenting}

Angioplasty was compared with surgery in the Carotid and Vertebral Artery Transluminal Angioplasty Study, a randomised clinical trial [CAVATAS Investigators, 2001]: the 30-day death and stroke rate of carotid surgery was $9.9 \%$ and that of angioplasty $10.0 \%$. We are currently waiting for the results of ongoing trials. The use of carotid 
angioplasty and stenting should be limited to welldesigned, well-conducted, randomised studies.

\section{Recommendations}

1 Carotid percutaneous transluminal angioplasty may be performed for patients with contra-indications to CEA or with stenosis at surgically inaccessible sites (level IV).

2 Carotid percutaneous transluminal angioplasty and stenting may be indicated for patients with re-stenosis after initial CEA or stenosis following radiation (level IV).

3 Patients should receive a combination of clopidogrel and aspirin immediately before, during and at least 1 month after stenting (level IV).

\section{Acute Stroke Management}

There are 5 mainstays in the treatment of acute stroke.

(1) Treatment of general conditions that need to be stabilised.

(2) Specific therapy directed against particular aspects of stroke pathogenesis, either recanalisation of a vessel occlusion or prevention of mechanisms leading to neuronal death in the ischaemic brain (neuroprotection).

(3) Prophylaxis and treatment of complications which may be either neurological (such as secondary haemorrhage, space-occupying oedema or seizures) or medical (such as aspiration, infections, decubital ulcers, deep venous thrombosis or pulmonary embolism).

(4) Early secondary prevention, which is aimed at reducing the incidence of early stroke recurrence.

(5) Early rehabilitation.

\section{Monitoring of Vital Neurological Functions in the \\ Stroke Unit or in a Normal Ward}

In all stroke patients, the neurological status and vital functions (blood pressure, pulse rate and temperature) should be continuously or regularly monitored. The neurological status is best monitored using validated neurological scales, such as the NIH Stroke Scale [Lyden et al., 1994], the Scandinavian Stroke Scale [Lindstrom et al., 1991] and the Glasgow Coma Scale [Teasdale and Jennet, 1976].

In selected cases with past medical history of cardiac disease and/or arrhythmias and in case of unstable blood pressure, on-line ECG monitoring is desirable. The electrodes for cardiac monitoring can also be used for respiratory monitoring, which is useful to detect respiration abnormalities during sleep [Iranzo et al., 2002; Turkington et al., 2002]. When instrumental monitoring is not feasible, repeat ECG, clinical checks of respiratory function and blood pressure measurements with automatic inflatable sphygmomanometry should be performed. Pulse oxymetry is useful for continuous monitoring in stroke units. It provides relevant information on the patient's respiratory status. A central venous catheter and occasionally central venous pressure monitoring is needed in severe stroke patients treated in specialised wards. Via a central venous catheter, indirect information on intravascular volume, cardiac function, and compliance within the venous system can be achieved.

\section{General Stroke Treatment}

The term 'general treatment' refers to treatment strategies aimed at stabilising the critically ill patient, in order to control systemic problems that may negatively influence stroke outcome and to provide an optimum physiological basis upon which specific therapeutic strategies may be applied. There is consensus that the management of general medical problems is the basis for stroke treatment [WHO Task Force, 1989; Brott and Reed, 1989; Adams et al., 1994; Hacke et al., 1995; European Ad Hoc Consensus Group, 1996]. General management of stroke patients includes respiratory and cardiac care, fluid and metabolic management, blood pressure control and perhaps treatment of elevated intracranial pressure (ICP). In addition, treatment of seizures and prophylactic measures concerning DVT, pulmonary embolism, dysphagia, aspiration pneumonia, other infections and decubital ulcer are part of the general treatment of the patients.

Most authors agree that adequate support of vital functions constitutes basic therapy. On the other hand, one has to keep in mind that even the proposed management of hypertension, hyperglycaemia or fever in stroke patients has never been tested prospectively.

\section{Pulmonary Function and Airway Protection}

Normal respiratory function and adequate blood oxygenation are required for stroke management, being important for the preservation of metabolic function in the ischaemic penumbra. However, there is no convincing prospective clinical evidence that oxygen supply at low flow rates is useful in human brain infarction [Ronning and Guldvog, 1999].

Respiratory function has to be monitored in order to detect and treat hypoxia. This may be consequent to extensive brainstem or hemispheric infarction, large brain haemorrhage, sustained seizure activity, or to complications such as severe pneumonia particularly in patients at risk of aspiration, heart failure, pulmonary embo- 
lism or exacerbation of chronic obstructive pulmonary disease. Ventilation may be particularly compromised during sleep [Iranzo et al., 2002]. Blood oxygenation is improved by the administration of 2-4 litres of $\mathrm{O}_{2}$ per minute via a nasal tube, when indicated. In the event of a severely compromised respiratory pattern, severe hypoxaemia or hyper-carbia, and in the unconscious patient (Glasgow Coma Scale $\leq 8$ ) at high risk for aspiration, early intubation may be necessary. Prognosis of stroke patients undergoing intubation is not invariably bad [Grotta et al., 1995; Berrouschot et al., 2000] with some series reporting a 1-year survival rate of about one third of the patients [Steiner et al., 1997]. Of course, before intubation is performed, the general prognosis, co-existing lifethreatening medical conditions and the presumed will of the patient and his/her family have to be taken into account.

\section{Cardiac Care}

Cardiac arrhythmias secondary to stroke, particularly AF [Broderick et al., 1992; Vingerhoets et al., 1993], are not unusual, while heart failure, acute MI or sudden death [Bamford et al., 1990; Broderick et al., 1992] may complicate the clinical course. Significant ECG alterations in the ST segments and the T waves and QT prolongation mimicking myocardial ischaemia may appear in the acute phase [Norris, 1983], and cardiac enzymes may be elevated after stroke [James et al., 2000]. Most of the events related to pre-existing coronary artery disease [Khechinashvili, 2002], but there may also be coincidental MI, with cerebral ischaemia [Furlan, 1987]. However, irrespective of previous cardiac disease, a correlation has been stressed between infarcts involving the insular cortex and cardiac complications [Oppenheimer et al., 1996].

Every stroke patient should have an initial ECG, while indications on continuous ECG monitoring are reported above.

Optimizing cardiac output with maintenance of a high normal blood pressure and a normal heart rate is the essential basis of stroke management. The central venous pressure should be maintained at approximately $8-10 \mathrm{~cm}$ $\mathrm{H}_{2} \mathrm{O}$, and its monitoring, although not frequently used in a normal ward, will give early warning of a volume deficiency or volume overload, which both have negative effects on cerebral perfusion. The intravascular volume must be kept stable. Among the inotropic agents, dobutamine has the advantage of increasing cardiac output without substantially affecting either heart rate or blood pressure. Dopamine may be particularly useful in patients with arterial hypotension or renal insufficiency. Increases in cardiac output may increase cerebral perfusion in areas, which have lost their autoregulative capacity after acute ischaemia. Restoration of normal cardiac rhythm using drugs, cardioversion, or pacemaker support should be performed in co-operation with internists or cardiologists, if necessary.

\section{Blood Pressure Management}

Blood pressure monitoring and treatment is a critical issue, since many patients with acute stroke have elevated blood pressure [Leonardi-Bee et al., 2002]. Some data would favour treatment [Hatashita et al., 1986; Davalos et al., 1990; Bowes et al., 1996; Fagan et al., 1998; Chamorro et al., 1998; Ahmed and Wahlgren, 2001; Leonardi-Bee et al., 2002], but evidence opposing treatment is also available [Jorgensen et al., 1994; Ahmed et al., 2000; Leonardi-Bee et al., 2002]. Cerebral blood flow autoregulation may be defective in an area of evolving infarction [Meyer et al., 1973]. Eames et al. [2002] showed that flow in the ischaemic penumbra is passively dependent on the mean arterial pressure. Hence, abrupt drops in blood pressure must be avoided if an adequate cerebral perfusion pressure is to be maintained. Moreover, blood pressure increase may be consequent to treatable conditions [Carlberg et al., 1991], and usually blood pressure spontaneously decreases during the first days after stroke onset [Britton et al., 1986; Jansen et al., 1987; Oppenheimer and Hachinski, 1992; Broderick et al., 1993; Harper et al., 1994].

A target systolic blood pressure of $180 \mathrm{~mm} \mathrm{Hg}$ and diastolic blood pressure of $100-105 \mathrm{~mm} \mathrm{Hg}$ is recommended in patients with prior hypertension. In other cases, lower blood pressure values are desirable (160-180/90-100 mm $\mathrm{Hg}$ ). Obviously, extremely high blood pressure levels are not acceptable. Systolic values over $220 \mathrm{~mm} \mathrm{Hg}$ or diastolic values over $120 \mathrm{~mm} \mathrm{Hg}$ (in some centres, especially in North America, thresholds of $240 \mathrm{~mm} \mathrm{Hg}$ systolic and $130 \mathrm{~mm} \mathrm{Hg}$ diastolic values are accepted) constitute an indication for early but cautious drug treatment, avoiding a drastic or abrupt reduction in blood pressure (tables 8,9$)$. There are only few other indications for immediate antihypertensive therapy. Treatment may be appropriate in the setting of concomitant acute myocardial ischaemia (although extreme lowering of blood pressure is deleterious for MI patients as well), cardiac insufficiency, acute renal failure or aortic arch dissection. In patients undergoing thrombolysis or heparin administration, systolic blood pressure above $180 \mathrm{~mm} \mathrm{Hg}$ should be avoided. In case the CT scan has shown a non-ischaemic cause of 
Table 8. Characteristics of selected antihypertensive drugs that may be used in acute stroke (modified from Kaplan [1990] and Ringleb et al. [1998])

\begin{tabular}{|c|c|c|c|c|}
\hline Oral drugs & Dose & $\begin{array}{l}\text { Onset } \\
\min \end{array}$ & $\begin{array}{l}\text { Duration } \\
\mathrm{h}\end{array}$ & Adverse effects \\
\hline \multicolumn{5}{|c|}{ Angiotensin-converting enzyme inhibitor } \\
\hline Captopril & $6-12.5 \mathrm{mg}$ s.c. & $15-30$ & $4-6$ & decrease in cerebral blood flow orthostatic hypotension \\
\hline \multicolumn{5}{|l|}{ Parenteral drugs } \\
\hline \multicolumn{5}{|c|}{ Central sympaticolytic } \\
\hline Clonidine & $\begin{array}{l}0.2 \mathrm{mg} \text { initial then } 0.1 \mathrm{mg} / \mathrm{h} \\
\text { up to } 0.8 \mathrm{mg}\end{array}$ & $5-15$ & $6-8$ & $\begin{array}{l}\text { profound hypotension; caution if combined with } \\
\text { diuretics }\end{array}$ \\
\hline \multicolumn{5}{|l|}{ Vasodilators } \\
\hline Nitroprusside & $0.25-10 \mu \mathrm{g} / \mathrm{kg} \mathrm{min}^{-1}$ & $1-5$ & & $\begin{array}{l}\text { nausea, vomiting, muscle twiching, sweating, } \\
\text { thiocyanate intoxication }\end{array}$ \\
\hline Nitroglycerin & $5-100 \mu \mathrm{g} / \mathrm{kg} \mathrm{min}^{-1}$ & $2-5$ & & tachycardia, headaches, vomiting \\
\hline Dihydralazin & $\begin{array}{l}6.5-20 \mathrm{mg} \text { i.v. bolus } \\
1.5-7.5 \mathrm{mg} / \mathrm{h}\end{array}$ & $1-2$ & $1-2$ & tachycardia, headaches \\
\hline \multicolumn{5}{|l|}{$\beta$-Blocker } \\
\hline Propranolol & $1-10 \mathrm{mg}$ i.v. & $1-2$ & $3-6$ & $\begin{array}{l}\beta \text {-blocker side-effects (e.g. bronchospasm, decreased } \\
\text { cardiac output, bradycardia) }\end{array}$ \\
\hline \multicolumn{5}{|l|}{$\alpha / \beta$-Blocker } \\
\hline Labetalol & $\begin{array}{l}20-80 \mathrm{mg} \text { i.v. bolus } \\
2 \mathrm{mg} / \mathrm{min} \text { i.v. infusion }\end{array}$ & $5-10$ & $3-5$ & vomiting, postural hypotension, nausea, dizziness \\
\hline \multicolumn{5}{|l|}{$\alpha$-Blocker } \\
\hline Urapidil & $\begin{array}{l}10-50 \mathrm{mg} \text { i.v. bolus } \\
9-30 \mathrm{mg} / \mathrm{h}\end{array}$ & $2-5$ & 3 & no serious side-effects \\
\hline \multicolumn{5}{|c|}{ Central sympatholytic } \\
\hline Clonidine & $0.075 \mathrm{mg}$ s.c. & $5-10$ & $3-5$ & initial blood pressure increase, sedation \\
\hline
\end{tabular}

The use of oral nifedipin is strongly discouraged.

stroke, such as subarachnoid haemorrhage, intracerebral haemorrhage or subdural haematoma, antihypertensive treatment may also be started.

The use of sublingual nifedipine should be avoided because of the risk of abrupt reduction of blood pressure [Grossman et al., 1996], possible ischaemic steal [Ahmed et al., 2000; Adams et al., 1994; Graham et al., 1982; Power, 1993; Jorgensen et al., 1994] and overshoot hypertension. Oral captopril (6.25-12.5 mg) may be used instead, but has a short duration of action and can have an abrupt effect. In North America, intravenous labetalol $(10 \mathrm{mg})$ is frequently recommended. Intravenous urapidil is increasingly used in this situation. Finally, sodium nitroprusside is sometimes recommended despite possible major sideeffects, such as reflex tachycardia and coronary artery ischaemia.

A low or normal-low blood pressure at stroke onset is unusual [Leonardi-Bee et al., 2002] and may be conse- quent to a large infarct, to cardiac failure or ischaemia, or sepsis. Blood pressure can be raised by adequate patient re-hydration with crystalloid (saline) or, occasionally, colloid solutions. Low cardiac output may need inotropic support.

\section{Glucose Metabolism}

An increase in serum glucose levels at hospital admission may be frequently found, due to previous known or unknown diabetes [Toni et al., 1992; Gray et al., 1987], even in non-diabetic patients [van Kooten et al., 1993].

High glucose levels are harmful in stroke [Pulsinelli et al., 1983; Davalos et al., 1990; Toni et al., 1994; Weir et al., 1997; Capes et al., 2001]. This is true not only for diabetic patients, whose metabolic derangement may be dramatically worsened in the acute stroke phase, but also for non-diabetic subjects [Weir et al., 1997; Capes et al., 2001]. Hence, temporary insulin treatment may become 
Table 9. Suggested antihypertensive treatment in acute ischaemic stroke (modified from Brott et al. [1994] and Ringleb et al. [1998]; availability of substances may vary between countries)

\begin{tabular}{lll}
\hline 1 & $\begin{array}{l}\text { Systolic BP } 180-220 \mathrm{~mm} \mathrm{Hg} \text { and/or diastolic } \\
\text { BP } 105-140 \mathrm{~mm} \mathrm{Hg}\end{array}$ & do not treat \\
\hline 2 & $\begin{array}{l}\text { Systolic BP } \geq 220 \mathrm{~mm} \mathrm{Hg} \text { and/or diastolic } \\
\text { BP } 120-140 \mathrm{~mm} \mathrm{Hg} \text {, on repeated measures }\end{array}$ & $\begin{array}{l}\text { captopril } 6.25-12.5 \mathrm{mg} \text { p.o./i.m. } \\
\text { labetalol } 5-20 \mathrm{mg} \text { i.v. }\end{array}$ \\
& $\begin{array}{l}\text { urapidil } 10-50 \mathrm{mg} \text { i.v., followed by } 4-8 \mathrm{mg} / \mathrm{h} \text { i.v. }{ }^{2} \\
\text { clonidine } 0.15-0.3 \mathrm{mg} \text { i.v. or s.c. } \\
\text { dihydralazine } 5 \mathrm{mg} \text { i.v. plus metoprolol } 10 \mathrm{mg}\end{array}$ \\
\hline 3 & Diastolic BP $\geq 140 \mathrm{~mm} \mathrm{Hg}$ & $\begin{array}{l}\text { nitroglycerin } 5 \mathrm{mg} \text { i.v., followed by } 1-4 \mathrm{mg} / \mathrm{h} \text { i.v. } \\
\text { sodium nitroprusside } 1-2 \mathrm{mg}\end{array}$ \\
& \\
\hline & $\begin{array}{l}\text { BP }=\text { Blood pressure. } \\
\text { Avoid labetalol in patients with asthma, cardiac failure, severe conduction abnormalities and bradycardia. }\end{array}$ \\
In patients with unstable conditions and rapidly fluctuating BP, alternating urapidil/labetalol and arterenol may \\
be used.
\end{tabular}

necessary. A blood glucose of $10 \mathrm{mmol} / \mathrm{l}$ or higher justifies immediate insulin titration. Unless the blood glucose is known, no glucose solution should be given to a stroke patient.

On the other hand, hypoglycaemia can rarely mimic an acute ischaemic infarction [Huff, 2002] and should be treated by intravenous dextrose bolus or infusion of 10$20 \%$ glucose, preferably via a central venous line.

\section{Body Temperature}

Experimentally, hyperthermia increases infarct size [Fukuda et al., 1999]. Fever is frequent over the initial 48 $\mathrm{h}$ of stroke onset [Corbett and Thornhill, 2000] and negatively influences clinical outcome [Reith et al., 1996; Castillo et al., 1999; Hajat et al., 2000]. On the other hand, it has to be remembered that infection is a risk factor for stroke [Syrjanen et al., 1988; Grau et al., 1999], and that many patients develop an infection after stroke [Grau et al., 1999; Georgilis et al., 1999]. Hence, search of a possible infection is recommended in order to start tailored treatment, though empirical antibiotic, antimycotic or antiviral treatment is not recommended in immunocompetent patients.

Small, randomised studies with high-dose antipyretics provide contradictory data on the usefulness of this approach [Dippel et al., 2001; Kasner et al., 2002], but treating an elevated temperature in stroke patients is advisable. Although there are no prospective data, one may consider to treat fever as early as the temperature reaches $37.5^{\circ} \mathrm{C}$.

European Stroke Initiative

Recommendations for Stroke Management

\section{Fluid and Electrolyte Management}

Stroke patients should have a balanced fluid and electrolyte status to avoid plasma volume contraction, which may influence brain perfusion and kidney function. Some degree of dehydration on admission is frequent and may be related to bad outcome [Bhalla et al., 2000]. Virtually all acute stroke patients need intravenous fluid therapy, with a more or less positive balance according to the level of dehydration. However, uncontrolled volume replacement may lead to cardiac failure and pulmonary oedema.

A slightly negative fluid balance is recommended in the presence of brain oedema. Hypotonic solutions $(\mathrm{NaCl}$ $0.45 \%$ or glucose $5 \%$ ) are contra-indicated due to the risk of brain oedema increase.

Serious electrolyte abnormalities are uncommon in patients with ischaemic stroke [Diringer, 1992]. However, electrolytes should be monitored daily and substituted accordingly. A peripheral venous access is usually sufficient for initial fluid management and blood sampling, while a central venous catheter is required in case of infusion of larger volumes of fluids or hyperosmolal solutions.

Recommendations (All Level IV)

1 Continuous cardiac monitoring is recommended in the first $48 \mathrm{~h}$ of stroke onset particularly in patients with: (a) previous known cardiac disease, (b) history of arrhythmias, (c) unstable blood pressure, (d) clinical signs/symptoms of heart failure, (e) abnormal baseline ECG and (f) infarct involving the insular cortex.

2 Oxygenation monitoring with pulse oxymetry is recommended.

Cerebrovasc Dis 2003;16:311-337 
$3 \mathrm{O}_{2}$ administration is recommended in case of hypoxaemia (blood gas analysis or $\mathrm{O}_{2 \text { sat }}<92 \%$ at pulse oxymetry).

4 Intubation is recommended in case of potentially reversible respiratory insufficiency.

5 Routine blood pressure lowering is not recommended, except for extremely elevated values $(>200-220 \mathrm{~mm} \mathrm{Hg}$ systolic blood pressure or $120 \mathrm{~mm} \mathrm{Hg}$ diastolic blood pressure for ischaemic stroke, $>180 / 105$ for haemorrhagic stroke) confirmed by repeated measurements.

6 Immediate antihypertensive therapy for more moderate hypertension is recommended in case of stroke and heart failure, aortic dissection, acute myocardial infarction, acute renal failure, thrombolysis or intravenous heparin, but should be applied cautiously.

7 Recommended target blood pressure in patients (a) with prior hypertension: 180/100-105 mm Hg, (b) without prior hypertension: $160-180 / 90-100 \mathrm{~mm} \mathrm{Hg}$ and (c) under thrombolysis avoid systolic blood pressure above $180 \mathrm{~mm} \mathrm{Hg}$.

8 Recommended drugs for blood pressure treatment: (a) intravenous labetalol or urapidil and (b) intravenous sodium nitroprusside, nitroglycerin or oral captopril.

9 Avoid nifedipine and any drastic blood pressure decrease.

10 Avoid and treat hypotension particularly in unstable patients by administering adequate amounts of fluids (see further on) and, when required, volume expanders and/or catecholamines (epinephrine $0.1-2 \mathrm{mg} / \mathrm{h}$ plus dobutamine $5-50 \mathrm{mg} / \mathrm{h}$ ).

11 Monitoring of serum glucose levels is recommended, particularly in known diabetic patients.

12 Glucose solutions are not recommended due to the detrimental effects of hyperglycaemia.

13 Treatment of serum glucose levels $>10 \mathrm{mmol} / \mathrm{l}$ with insulin titration is recommended.

14 Immediate correction of hypoglycaemia is recommended by intravenous dextrose bolus or infusion of $10-20 \%$ glucose.

15 Treatment of body temperature $\geq 37.5^{\circ} \mathrm{C}$ is recommended.

16 In case of fever, the search of a possible infection (site and aetiology) is recommended, in order to start tailored antibiotic treatment.

17 Antibiotic, antimycotic or antiviral prophylaxis is not recommended in immunocompetent patients.

18 Monitoring and correction of electrolyte and fluid disturbances are recommended.

19 Hypotonic solutions ( $\mathrm{NaCl} 0.45 \%$ or glucose $5 \%$ ) are contra-indicated due to the risk of brain oedema increase consequent to reduction of plasma osmolality.

\section{Specific Treatment}

\section{Thrombolytic Therapy}

\section{Intravenous Recombinant Tissue Plasminogen \\ Activator}

Thrombolytic therapy with recombinant tissue plasminogen activator (rtPA; $0.9 \mathrm{mg} / \mathrm{kg}$ body weight) given within $3 \mathrm{~h}$ after stroke onset to patients with acute isch- aemic stroke significantly improves outcome [The $\mathrm{Na}$ tional Institute of Neurological Disorders and Stroke rtPA Stroke Study Group, NINDS, 1995], with an NNT of 7. Two European trials, ECASS and ECASS II, tested a 6-hour time window and did not show statistically significant superiority of rtPA for the primary endpoints [Hacke et al., 1995; Hacke et al., 1998].

Eight trials have tested rt-PA in 2,889 patients. Overall, there was a significant reduction in the number of patients with a poor functional outcome (combined death or dependency) at the end of follow-up (OR 0.83, 95\% CI 0.73-0.94). The subgroup of patients treated within $3 \mathrm{~h}$ showed a greater reduction in poor functional outcome with thrombolysis (OR $0.58,95 \%$ CI $0.46-0.74$ ) with no adverse effect on death [Hacke et al., 1999; Wardlaw and Warlow, 1999; Wardlaw, 2001].

A pooled analysis of individual data of the $6 \mathrm{rtPA}$ trials confirms that thrombolysis works at least until $4.5 \mathrm{~h}$ and potentially up to $6 \mathrm{~h}$ after stroke onset [The ATLANTIS, ECASS, and NINDS rt-PA Study Group Investigators, 2003]. Caution is advised before giving intravenous rtPA to persons with severe stroke (NIH Stroke Scale $>25$ ), or if the CT demonstrates extended early changes of a major infarction, such as sulcal effacement, mass effect and oedema.

Thrombolytic therapy should only be given if the diagnosis is established by a physician who has expertise in the diagnosis of stroke, and a CT of the brain is assessed by physicians who have expertise in reading this imaging study. Because the use of thrombolytic drugs carries the real risk of major bleeding, the risks and potential benefits of rtPA should be discussed whenever possible with the patient and family before treatment is initiated.

Intravenous administration of rtPA more than $3 \mathrm{~h}$ after stroke should only be given in an institutional protocol as experimental therapy or within a multicentre clinical trial. Continuous auditing of routine use of thrombolytic therapy is advisable. Safety monitoring of treatment (SITS-MOST) is a condition for approval of rtPA in the European Union.

\section{Other Thrombolytic Approaches}

Intravenous streptokinase has been shown to be associated with an unacceptable risk of haemorrhage and haemorrhage-associated death [The Multicenter Acute Stroke Trial - Europe Study Group, 1996; Donnan et al., 1995].

Intra-arterial thrombolytic therapy of occlusions of the proximal part of the MCA, using pro-urokinase, has been shown to be significantly associated with better outcome in a randomised trial. This treatment is safe and efficacious in 
a 6-hour time window, but it requires super-selective angiography and is only available in selected centres [Furlan et al., 1999]. Intra-arterial treatment of acute basilar occlusion with urokinase or rtPA is frequently used in selected centres, but has not been subjected to a randomised trial [Brandt et al., 1996].

\section{Defibrinogenating Enzymes}

Ancrod is a defibrinogenating enzyme which was shown to improve outcome after acute ischaemic stroke if given within $3 \mathrm{~h}$ after stroke onset and over 5 days [Sherman, 1999]. Recently, a European trial testing ancrod treatment in a 6-hour time window has been terminated prematurely and did not confirm the US findings.

\section{Recommendations}

1 Intravenous rtPA $(0.9 \mathrm{mg} / \mathrm{kg}$, maximum $90 \mathrm{mg})$, with $10 \%$ of the dose given as a bolus followed by an infusion lasting $60 \mathrm{~min}$, is the recommended treatment within $3 \mathrm{~h}$ of onset of ischaemic stroke (level I).

2 The benefit from the use of intravenous rtPA for acute ischaemic stroke beyond $3 \mathrm{~h}$ after onset of the symptoms is smaller, but present up to $4.5 \mathrm{~h}$ (level I).

3 Intravenous rtPA is not recommended when the time of onset of stroke cannot be ascertained reliably; this includes persons whose strokes are recognised upon awakening (level IV).

4 Intravenous administration of streptokinase is dangerous and not indicated for the management of persons with ischaemic stroke (level I).

5 Data on the efficacy and safety of any other intravenously administered thrombolytic drugs are not available to provide a recommendation.

6 Intra-arterial treatment of acute MCA occlusion in a 6-hour time window using pro-urokinase results in a significantly improved outcome (level II).

7 Acute basilar occlusion may be treated with intra-arterial therapy in selected centres in an institutional protocol as experimental therapy or within a multicentre clinical trial (level IV).

8 Ancrod cannot presently be recommended for use in acute ischaemic stroke outside the setting of clinical trials.

\section{Aspirin}

The results of 2 very large randomised, non-blinded intervention studies indicate that aspirin given within 48 $\mathrm{h}$ after stroke (International Stroke Trial, Chinese Acute Stroke Trial) reduces mortality and rate of recurrent stroke minimally, but statistically significantly [International Stroke Trial Collaborative Group, 1997; Chinese Acute Stroke Trial, 1997], with an NNT of 111.
Table 10. Possible remaining indications for heparin treatment after stroke

1 Stroke due to cardiac emboli with high risk of re-embolisation (artificial valves, AF, MI with mural thrombi, left atrial thrombosis)

2 Coagulopathies such as protein $\mathrm{C}$ and $\mathrm{S}$ deficiency, APC resistance

3 Symptomatic dissection of extracranial arteries

4 Symptomatic extracranial and intracranial stenoses

a Symptomatic ICS prior to operation

b Crescendo TIAs or stroke in progression

5 Sinus-venous thrombosis

$\mathrm{APC}=$ Activated protein $\mathrm{C}$.

\section{Early Anticoagulation}

Early anticoagulation with unfractionated heparin (UFH) has been used frequently in treatment after acute ischaemic stroke. Unfortunately, none of the early anticoagulation trials that have been performed in the past years selected full anticoagulant doses of UFH as the therapeutic option. Subcutaneous UFH at low or moderate doses [International Stroke Trial Collaborative Group, 1997], nadroparin [Kay et al., 1995; Hommel et al., 1998], certoparin [Diener et al., 2001], tinzaparin [Bath et al., 2001], dalteparin [Berge et al., 2000] and intravenous danaparoid [The TOAST Publication Committee, 1998] failed to show an overall benefit of treatment. While there was some kind of improvement in outcome or reduction in stroke recurrence rates, this was almost always counterbalanced by an increased number of haemorrhagic complications. In addition, most investigators believe that heparin is not a standard therapy for all stroke subtypes. Full-dose heparin may be used when there are selected indications such as cardiac sources with high risk of reembolism, arterial dissection or high-grade arterial stenosis prior to surgery (table 10). Some investigators found greater functional recovery the sooner heparin was administered, suggesting that in addition to its role to prevent early stroke recurrence, the agent also has therapeutic properties [Chamorro, 2001], including down-regulation of inflammatory markers [Chamorro et al., 2002]. Contra-indications for the treatment with heparin include large infarcts (e.g. more than 50\% of MCA territory), uncontrollable arterial hypertension and advanced microvascular changes in the brain.

\section{Haemodilution}

Several large clinical trials of isovolaemic haemodilution failed to demonstrate a decline in mortality or dis- 
ability with treatment [Strand, 1992; Italian Acute Stroke Study Group, 1988; Scandinavian Stroke Study Group, 1987; The Hemodilution in Stroke Study Group, 1989]. Hypervolaemic haemodilution has been examined in small randomised trials with conflicting results.

\section{Neuroprotection}

No neuroprotective trial has shown improved outcome after stroke on its predefined primary endpoint. Current$1 \mathrm{y}$, there is no recommendation to treat patients with neuroprotective drugs after ischaemic stroke.

\section{Recommendations}

1 Aspirin (100-300 mg per day) may be given within $48 \mathrm{~h}$ after ischaemic stroke (level I).

2 If thrombolytic therapy is planned, no aspirin should be given.

3 Aspirin is not allowed for $24 \mathrm{~h}$ after thrombolytic therapy.

4 There is no recommendation for general use of heparin, lowmolecular weight heparin or heparinoids after ischaemic stroke (level I).

5 Full-dose heparin may be used when there are selected indications such as cardiac sources with high risk of re-embolism, arterial dissection, or high-grade arterial stenosis prior to surgery (level IV).

6 Haemodilution therapy is not presently recommended for the management of patient with acute ischaemic stroke (level I).

7 Currently, there is no recommendation to treat stroke patients with neuroprotective substances (level I).

\section{Prevention and Treatment of Complications}

Acute stroke predisposes to medical complications [Davenport et al., 1996; Langhorne et al., 2000], such as pneumonia, urinary tract infections, malnutrition or volume depletion. Patients may also suffer from deep venous thrombosis and pulmonary embolism. Early supportive care and monitoring of physiological parameters may prevent such complications. This is best done in a dedicated stroke unit with experienced staff and early mobilisation. Immobility may lead to infections, contractions and decubital ulcers.

\section{Aspiration and Pneumonia}

Bacterial pneumonia is one of the most important complications in stroke patients [Davenport et al., 1996; Langhorne et al., 2000; Weimar et al., 2002b], the majority being caused by aspiration [Horner et al., 1988]. Since aspiration may be detectable by videofluoroscopy in as many as $50 \%$ of patients during the initial days after stroke onset, oral feeding should be withheld until the patient has demonstrated both intact swallowing with small amounts of water and intact coughing to command. Aspiration is frequently found, both in patients with reduced consciousness and in those with swallowing disturbances. Nasogastric tube feeding is adequate for shortterm enteral feeding, but a percutaneous enteral gastrostomy (PEG) should be inserted once it is clear that protracted enteral feeding will be required. As a rule of thumb, a PEG is indicated when abnormal swallowing is predicted for periods longer than 1 month.

Nasogastric tube or PEG feeding through avoidance of swallowing may be helpful in prevention of aspiration pneumonia. They do not completely reduce the risk, however, since reflux of liquid feed can itself promote aspiration. Other reasons for pneumonia include hypostasis, diminished cough and immobilisation. Frequent changes of the patient's position in bed and pulmonary physical therapy may prevent this type of pneumonia.

\section{Urinary Tract Infection}

Urinary tract infection is incidental in as many as $40 \%$ of patients dying from stroke [Silver et al., 1984]. Urinary retention is frequent in the early phase after stroke and will require insertion of a urine catheter or supra-pubic catheter. Otherwise, incontinent patients should be managed with a condom catheter or 'pad and pants'. The majority of hospital-acquired urinary tract infections are associated with the use of indwelling catheters [Gerberding, 2002]. In non-stroke patients, supra-pubic catheters are considered to carry lower risk of infection [Vandoni et al., 1994], whereas intermittent catheterisation has not been shown to have a reduced risk. Once urinary infection is diagnosed, appropriate antibiotics should be chosen. To avoid bacterial resistance developing, prophylactic antibiotics are best avoided.

\section{Pulmonary Embolism and DVT}

Pulmonary embolism is the cause of death in up to $25 \%$ of patients dying following ischaemic cerebral infarction. Nevertheless, the incidence of symptomatic pulmonary embolism and DVT is now $<5 \%$ presumably reflecting modern clinical practice and admission to a stroke unit. The risk of DVT and pulmonary embolism can be reduced by early hydration and early mobilisation. Although graded compression stockings are effective in preventing venous thromboembolism, in surgical patients, their efficacy after stroke is unproven. Whilst subcutaneous heparin or low-molecular-weight heparin reduce venous thromboembolism, their effect is counterbalanced by an increase in haemorrhagic complications. Prophy- 
laxis with subcutaneous low-dose heparin $(5,000$ i.u. twice daily) or low-molecular-weight heparins is reasonable in patients at particularly high risk of DVT or pulmonary embolism.

\section{Decubital Ulcer}

Frequent turning of immobilised patients is useful for prevention of decubital ulcers. The skin of the incontinent patient must be kept dry. For patients at particularly high risk, an air-filled or fluid-filled mattress system should be used. If decubital ulcers do not respond to conservative therapy, antibiotic therapy may be justified for several days, preceding definitive surgical debridement.

\section{Seizures}

Partial (focal) or secondary generalised epileptic attacks may occur in the acute phase of ischaemic stroke. Post-stroke epilepsy may develop in $3-4 \%$ of cases [Olsen, 2001].

Standard intravenous and oral anti-epileptic drugs are in general used. There is no evidence that prophylactic anticonvulsive treatment is beneficial.

\section{Agitation}

Agitation and confusion are rarely caused by the stroke, but are more frequently a symptom of other complications such as fever, volume depletion or infection. Adequate treatment of the underlying cause must precede any type of sedation or antipsychotic treatment.

\section{Recommendations}

1 Low-dose subcutaneous heparin or low-molecular-weight heparins should only be considered for patients at high risk of DVT or pulmonary embolism (level II).

2 The incidence of venous thromboembolism may be reduced through early re-hydration and mobilisation and graded compression stockings (level IV).

3 Infections after stroke should be treated with appropriate antibiotics.

4 Aspiration pneumonia may not be prevented by nasogastric feeding (level IV).

5 Early mobilisation is helpful to prevent numerous complications after stroke including aspiration pneumonia, DVT and decubital ulcers (level IV).

6 Administration of anticonvulsants to prevent recurrent seizures is strongly recommended (level III).

7 Prophylactic administration of anticonvulsants to patients with recent stroke who have not had seizures is not recommended level IV).

\section{Brain Oedema and Elevated ICP}

Ischaemic brain oedema occurs during the first 24$48 \mathrm{~h}$ after stroke onset and is the main reason for early [Toni et al., 1995; Davalos et al., 1999] and late [Davalos et al., 1999] clinical deterioration. The most worrisome situation is that of younger patients with complete MCA infarction, in whom brain oedema and elevated ICP may lead to herniation within 2-4 days after onset of symptoms and to death in about $80 \%$ of cases with standard treatment [Rieke et al., 1995; Hacke et al., 1996; Steiner et al., 2001].

\section{Medical Therapy}

Basic management of elevated ICP following stroke includes head positioning at an elevation of up to $30^{\circ}$, avoidance of noxious stimuli, pain relief, appropriate oxygenation and normalising body temperature. If ICP monitoring is available, cerebral perfusion pressure should be kept $>70 \mathrm{~mm} \mathrm{Hg}$ [Unterberg et al., 1997]. Although strong evidence is lacking [Righetti et al., 2002; Bereczki et al., 2001], osmotherapy with $10 \%$ glycerol usually given intravenously (4 $250 \mathrm{ml}$ of $10 \%$ glycerol over 30 $60 \mathrm{~min}$ ) or intravenous mannitol $25-50 \mathrm{~g}$ every $3-6 \mathrm{~h}$ is the first medical treatment to be used if clinical and/or radiological signs of space-occupying oedema occur. Hypertonic saline solutions given intravenously $(5 \times 100 \mathrm{ml}$ saline 3\%) [Shackford et al., 1992; Schwarz et al., 1998; Schwarz et al., 2002] are probably similarly effective, though data at present available are not definitive [Qureshi et al., 1998; Prough et al., 1998]. Hypotonic and glucose-containing solutions should be avoided as replacement fluids. Dexamethasone and corticosteroids are not useful for brain oedema treatment after stroke [Qizilbash et al., 2002]. Short-acting barbiturates such as thiopental given as a bolus can quickly and significantly reduce ICP, but the effect is short lived and may be exploited only to treat an acute crisis, e.g. prior to operation. Barbiturate treatment requires ICP and EEG monitoring and careful monitoring of haemodynamic parameters, as a significant blood pressure drop may occur. ICP monitoring is also required when Tris (hydroxy-methyl) aminomethane buffer solution is used after osmotherapy and barbiturate failure [Steiner et al., 2001].

Volume loading by vasopressor induced hypertension may be attempted in case of severely compromised cerebral perfusion pressure, but haemodynamic monitoring and intensive care facilities are required [Kaste and Roine, in press]. 


\section{Hypothermia}

Hypothermia was shown to be neuroprotective after cardiac arrest [Bernard et al., 2002, The Hypothermia after Cardiac Arrest Study Group, 2002]. Mild hypothermia (i.e. brain temperature between 32 and $33^{\circ} \mathrm{C}$ ) reduces the case fatality rate of patients with severe MCA infarcts, but causes a number of severe side-effects which may be encountered during therapy over several days [Schwab et al., 1998; Schwab et al., 2002]. The number of studied patients is still too small to draw any decisive conclusions; however, this method is feasible and will be tested prospectively in randomised trials. One problem is recurrent ICP crisis, which was almost exclusively found during re-warming [Steiner et al., 2001]. Moreover, in a comparative trial, hypothermia had more severe sideeffects than decompressive surgery for malignant MCA infarction [Georgiadis et al., 2002].

\section{Decompressive Surgery}

Malignant MCA Infarction. The rationale of decompressive surgery is to allow expansion of the oedematous tissue to reduce ICP, to increase perfusion pressure, and to preserve cerebral blood flow by preventing further compression of the collateral vessels. In prospective case series, surgical, decompressive therapy in hemispheric space-occupying infarction lowered mortality from 80 down to $30 \%$ without increasing the rate of severely disabled survivors [Schwab 1995; Rieke et al., 1995; Mori et al., 2001]. Early decompressive surgery within the first $24 \mathrm{~h}$ after stroke onset can reduce mortality even more markedly [Schwab et al., 1998]. Prospective, multicentre study protocols have recently been developed and are underway.

Cerebellar Infarction. Ventriculo-stomy to reveal hydro-cephalus and decompressive surgery is considered the treatment of choice of a space-occupying cerebellar infarction, although the scientific basis for this is not more solid than for hemispheric infarction. Comatose patients with space-occupying cerebellar infarctions have a mortality of about $80 \%$ if treated conservatively. This high mortality can be lowered down to less than $30 \%$ if decompressive surgery is performed [Heros, 1992; Rieke et al., 1993]. Like in space-occupying supratentorial infarction, the operation should be performed before signs of herniation are present. The prognosis among survivors is very good, even if they were comatose when the operation was performed. It should be noted, however, that these are the results of open, small or medium-sized case series, one of them being prospective [Rieke et al., 1993], the remainder being mostly retrospective. Data from a controlled, randomised trial are lacking.

\section{Recommendations}

1 Osmotherapy is recommended for patients whose condition is deteriorating secondary to increased ICP, including those with herniation syndromes (level IV).

2 Ventriculostomy or surgical decompression and evacuation of large cerebellar infarctions that compress the brain stem is justified (level III)

3 Surgical decompression and evacuation of a large hemispheric infarction can be a life-saving measure and survivors may have a residual neurological deficit that allows an independent life (level III).

\section{References}

Abbott R, Yin Y, Reed D, Yano K: Risk of stroke in male cigarette smokers. N Engl J Med 1986; 315:717-720.

Aboderin I, Venables G, for the Pan European Consensus Meeting on Stroke Management: Stroke management in Europe. J Intern Med 1996;240:173-180.

Adams HP Jr, Brott TG, Crowell RM, Furlan AJ, Gomez CR, Grotta J, Helgason CM, Marler JR, Woolson RF, Zivin JA, et al: Guidelines for the management of patients with acute ischemic stroke. A statement for healthcare professionals from a special writing group of the Stroke Council, American Heart Association Stroke 1994;25:1901-1914.

Adams HP Jr, Adams RJ, Brott T, del Zoppo GJ, Furlan A, Goldstein LB, Grubb RL, Higashida R, Kidwell C, Kwiatkowski TG, Marler JR, Hademenos GJ; Stroke Council of the American Stroke Association: Guidelines for the ear- ly management of patients with ischemic stroke: A scientific statement from the Stroke Council of the American Stroke Association. Stroke 2003;34:1056-1083.

Ahmed N, Nasman P, Wahlgren NG: Effect of intravenous nimodipine on blood pressure and outcome after acute stroke. Stroke 2000;31: 1250-1255.

Ahmed N, Wahlgren G: High initial blood pressure after acute stroke is associated with poor functional outcome. J Intern Med 2001;249:467473.

Algra A, van Gijn J: Aspirin at any dose above $30 \mathrm{mg}$ offers only modest protection after cerebral ischaemia. J Neurol Neurosurg Psychiatry 1996;60:197-199.

ALLHAT Officers and Coordinators for the ALLHAT Collaborative Research Group: Major outcomes in moderately hypercholesterolemic, hypertensive patients randomized to pravastatin vs usual care: The Antihypertensive and
Lipid-Lowering Treatment to Prevent Heart Attack Trial (ALLHAT-LLT). JAMA 2002; 288:2998-3007.

American Diabetes Association: Aspirin treatment in diabetes. Diabetes Care 2000;23(suppl 1): S61-S62.

Antiplatelet Trialists' Collaboration: Collaborative meta-analysis of randomised trials of antiplatelet therapy for prevention of death, myocardial infarction, and stroke in high risk patients. BMJ 2002;324:71-86.

Asplund K, Marke L-A, Terent A, Gustafsson C, Wester P: Costs and gains in stroke prevention: European perspective. Cerebrovasc Dis 1993; 3(suppl):34-42.

Baker WH, Howard VJ, Howard G, Toole JF, for the ACAS investigators: Effect of contralateral occlusion on long-term efficacy of endarterectomy in the Asymptomatic Carotid Atherosclerosis Study (ACAS). Stroke 2000;31:2330 2334

The European Stroke Initiative Executive Committee and the EUSI Writing Committee 
Bamford J, Dennis M, Sandercock P, Burn J, Warlow $\mathrm{C}$ : The frequency, causes and timing of death within 30 days of a first stroke. The Oxfordshire Community Stroke Project. J Neurol Neurosurg Psychiatry 1990;53:824829.

Barber PA, Zhang J, Demchuk AM, Hill MD, Buchan AM: Why are stroke patients excluded from TPA therapy? An analysis of patients eligibility. Neurology 2001;56:1015-1020.

Barnett HJ, Taylor DW, Eliasziw M, Fox AJ, Ferguson GG, Haynes RB, Rankin RN, Clagett GP, Hachinski VC, Sackett DL, Thorpe KE, Meldrum HE: Benefit of carotid endarterectomy in patients with symptomatic moderate or severe stenosis. N Engl J Med 1998;339:14151425.

Bath PM, Lindenstrom E, Boysen G, De Deyn P Friis P, Leys D, Marttila R, Olsson J, O’Neill D, Orgogozo J, Ringelstein B, van der Sande J, Turpie AG: Tinzaparin in acute ischaemic stroke (TAIST): A randomised aspirin-controlled trial. Lancet 2001;358:702-710.

Becker K, Fruin M, Gooding T, Tirschwell D, Love $\mathrm{P}$, Mankowski T: Community-based education improves stroke knowledge. Cerebrovasc Dis 2001;11:34-43.

Benavente O, Moher D, Pham B: Carotid endarterectomy for asymptomatic carotid stenosis: A meta-analysis. BMJ 1998;317:1477-1480.

Bereczki D, Liu M, do Prado GF, Fekete I: Mannitol for acute stroke. Cochrane Database Syst Rev 2001;(1):CD001153.

Berge E, Abdelnoor M, Nakstad PH, Sandset PM: Low molecular-weight heparin versus aspirin in patients with acute ischaemic stroke and atrial fibrillation: A double-blind randomised study. HAEST Study Group. Heparin in Acute Embolic Stroke Trial. Lancet 2000;355:12051210 .

Bernabei R, Landi F, Gambassi G, et al: Randomised trial of impact of model of integrated care and case management for older people living in the community. BMJ 1998:316:1348-1351.

Bernard SA, Gray TW, Buist MD et al: Treatment of comatose survivors of out-of-hospital cardiac arrest with induced hypothermia. N Engl J Med 2002;346:557-563.

Berrouschot J, Rossler A, Koster J, Schneider D: Mechanical ventilation in patients with hemispheric ischemic stroke. Crit Care Med 2000; 28:2956-2961.

Bhalla A, Sankaralingam S, Dundas R, Swaminathan R, Wolfe CD, Rudd AG: Influence of raised plasma osmolality on clinical outcome after acute stroke. Stroke 2000;31:2043-2048.

Bhatt DL, Kapadia SR, Yadav JS, Topol EJ: Update on clinical trials of antiplatelet therapy for cerebrovascular diseases. Cerebrovasc Dis 2000;10(suppl 5):34-40.

Biller J, Feinberg W, Castaldo J, Whittemore A, Harbaugh R, Dempsey R, Caplan L, et al: Guidelines for carotid endarterectomy: A statement for healthcare professionals from a Special Writing Group of the Stroke Council, American Heart Association. Circulation 1998, 97:501-509.

Bowes MP, Zivin JA, Thomas GR, Thibodeaux H, Fagan SC: Acute hypertension, but not throm- bolysis, increases the incidence and severity of hemorrhagic transformation following experimental stroke in rabbits. Exp Neurol 11996;41: 40-46.

Brainin M, Bornstein N, Boysen G, Demarin V for the EFNS Task Force on Acute Neurological Stroke Care: Acute neurological stroke care in Europe: results of the European stroke care inventory. Eur J Neurol 2000;7:5-10.

Brainin M, Kaste M, Czlonkowska A et al. for the European Federation of Neurological Societies Task Force on Acute Neurological Stroke Care: The role of European neurology. Eur J Neurol 1997:4:435-441.

Brainin M, Steiner M: Acute stroke units in Austria are being set up on a national level following evidence-based recommendations and structural quality criteria. Cerebrovasc Dis 2003; 15(suppl 1):29-32.

Brandt $\mathrm{T}$, von Kummer R, Müller-Küppers M, Hacke W: Thrombolyic therapy of acute basilar artery occlusion: Variables affecting recanalization and outcome. Stroke 1996;27:875-881.

Britton M, Carlsson A, de Faire U: Blood pressure course in patients with acute stroke and matched controls. Stroke 1986;17:861-864.

Broderick J, Brott T, Barsan W, Clarke Haley E, Levy D, Marler J, Sheppard G, Blum C: Blood pressure during the first minutes of focal cerebral ischemia. Ann Emerg Med 1993;22:1438.

Broderick JP, Phillips SJ, O'Fallon WM, Frye RL, Whisnant JP: Relationship of cardiac disease to stroke occurrence, recurrence, and mortality Stroke 1992;23:1250-1256.

Brott T, Fieschi C, Hacke W: General therapy of acute ischemic stroke; in Hacke W, Hanley DF, Einhäupl K, Bleck Berlin TP (eds): Neurocritical Care. Heidelberg, Springer, 1994, pp 553577.

Brott T, Reed RL: Intensive care for acute stroke in the community hospital setting. The first 24 hours. Stroke 1989;20:694-697.

Camerlingo M, Casto L, Censori B, Ferraro B, Gazzaniga G, Partziguian T, Signore M, Panagia C, Fascendini A, Cesana BM, Mamoli A: Experience with a questionnaire administered by emergency medical service for pre-hospital identification of patients with acute stroke. Neurol Sci 2001;22:357-361.

Cannegieter S, Rosendaal F, Witzen A, Van Der Meer F, Vandenbroucke J, Briët E: Optimal oral anticoagulation therapy in patients with mechanical heart valves. N Engl J Med 1995; 333:11-17.

Capes SE, Hunt D, Malmberg K, Pathak P, Gerstein HC: Stress hyperglycemia and prognosis of stroke in nondiabetic and diabetic patients: Asystematic overview. Stroke 2001;32:24263223.

CAPRIE Steering Committee: A randomised, blinded trial of clopidogrel versus aspirin in patients at risk of ischaemic events (CAPRIE). Lancet 1996;348:1329-1339.

Carlberg B, Asplund K, Hagg E: Factors influencing admission blood pressure levels in patients with acute stroke. Stroke 1991;22:527-530.

Castillo J, Davalos A, Noya M: Aggravation of acute ischemic stroke by hyperthermia is relat- ed to an excitotoxic mechanism. Cerebrovasc Dis 1999;9:22-27.

CAVATAS Investigators: Endovascular versus surgical treatment in patients with carotid stenosis in the Carotid and Vertebral Artery Transluminal Angioplasty Study (CAVATAS): A randomised trial. Lancet 2001;357:1729-1737.

Chambers BR, You RX, Donnan GA: Carotid endarterectomy for asymptomatic carotid stenosis (Cochrane review); in: Cochrane Library, Issue 4, 2002.

Chamorro A: Immediate anticoagulation in acute focal brain ischemia revisited: Gathering the evidence. Stroke 2001;32:577-578.

Chamorro A, Cervera A, Castillo J, Davalos A, Aponte JJ, Planas AM: Unfractionated heparin is associated with a lower rise of serum vascular cell adhesion molecule-1 in acute ischemic stroke patients. Neurosci Lett 2002;16;328: 229-232.

Chamorro A, Vila N, Ascaso C, Elices E, Schonewille W, Blanc R: Blood pressure and functional recovery in acute ischemic stroke. Stroke 1998;29:1850-1853.

Chinese Acute Stroke Trial (CAST): Randomised placebo-controlled trial of early aspirin use in 20,000 patients with acute ischaemic stroke. Lancet 1999;349:1641-1649.

Colditz GA, Bonita R, Stampfer MJ, Willett WC, Rosner B, Speizer FE, Hennekens CH: Cigarette smoking and risk of stroke in middle-aged women. N Engl J Med 1988;318:937-941.

Corbett D, Thornhill J: Temperature modulation (hypothermic and hyperthermic conditions) and its influence on histological and behavioral outcomes following cerebral ischemia. Brain Pathol 2000;10:145-152.

Dahlof B, Devereux RB, Kjeldsen SE, Julius S, Beevers G, Faire U, Fyhrquist F, Ibsen H, Kristiansson $\mathrm{K}$, Lederballe-Pedersen $\mathrm{O}$, Lindholm LH, Nieminen MS, Omvik P, Oparil S, Wedel $\mathrm{H}$ : Cardiovascular morbidity and mortality in the Losartan Intervention For Endpoint reduction in hypertension study (LIFE): A randomised trial against atenolol. Lancet 2002;359: 995-1003.

Davalos A, Cendra E, Teruel J, Martinez M, Genis D: Deteriorating ischemic stroke: Risk factors and prognosis. Neurology 1990;40:1865-1869.

Davalos A, Toni D, Iweins F, Lesaffre E, Bastianello S, Castillo J: Neurological deterioration in acute ischemic stroke: Potential predictors and associated factors in the European cooperative acute stroke study (ECASS). Stroke 1999;30: 2631-2636.

Davenport RJ, Dennis MS, Wellwood I, Warlow CP: Complications after acute stroke. Stroke 1996;27:415-420.

Derex L, Adeleine P, Nighoghossian N, Honnorat $\mathrm{J}$, Trouillas P: Factors influencing early admission in a French stroke unit. Stroke 2002;33: 153-159.

Diener HC, Cunha L, Forbes C, Sivenius J, Smets $\mathrm{P}$, Lowenthal A: European Stroke Prevention Study. 2. Dipyridamole and acetylsalicylic acid in the secondary prevention of stroke. J Neurol Sci 1996;143:1-13.

Diener HC, Ringelstein EB, von Kummer $\mathrm{R}$, Langohr HD, Bewermeyer $\mathrm{H}$, Landgraf $\mathrm{H}$, 
Hennerici M, Welzel D, Grave M, Brom J, Weidinger G: Treatment of acute ischemic stroke with the low-molecular-weight heparin certoparin: Results of the TOPAS trial. Therapy of Patients With Acute Stroke (TOPAS) Investigators. Stroke 2001;32:22-29.

Di Mascio R, Marchili R, Tognoni G: Cholesterol reduction and stroke occurrence: An overview of randomized clinical trials. Cerebrovasc Dis 2000;10:85-92.

Dippel DW, van Breda EJ, van Gemert HM, van der Worp HB, Meijer RJ, Kappelle LJ, Koudstaal PJ: Effect of paracetamol (acetaminophen) on body temperature in acute ischemic stroke: A double-blind, randomized phase II clinical trial. Stroke 2001;32:1607-1612.

Diringer MN: Management of sodium abnormalities in patients with CNS disease. Clin Neuropharmacol 1992;15:427-447.

Donnan G, Davis S, Chambers B, Gates P, Hankey G, McNeil J, Rosen D, et al.: Trials of streptokinase in severe acute ischaemic stroke. Lancet 1995;345:578-579.

Dressler FA, Craig WR, Castello R, Labovitz AJ: Mobile aortic atheroma and systemic emboli: Efficacy of anticoagulation and influence of plaque morphology on recurrent stroke. J Am Coll Cardiol 1998;31:134-138.

Duncan PW: Synthesis of intervention trials to improve motor recovery following stroke. Top Stroke Rehabil 1997;3:1-20.

Eames PJ, Blake MJ, Dawson SL, Panerai RB, Potter JF: Dynamic cerebral autoregulation and beat to beat blood pressure control are impaired in acute ischaemic stroke. J Neurol Neurosurg Psychiatry 2002;72:467-472.

Echiverri HC, Rubino FA, Gupta SR, Gujrati M: Fusiform aneurysm of the vertebrobasilar arterial system. Stroke 1989;20:1741-1747.

ETDRS Investigators: Aspirin effects on mortality and morbidity in patients with diabetes mellitus. Early Treatment Diabetic Retinopathy Study report 14. JAMA 1992;268:1292-1300.

European Stroke Initiative: European Stroke Initiative recommendations for stroke management. Cerebrovasc Dis 2000;10:335-351.

Evenson KR, Rosamond WD, Morris DL: Prehospital and in-hospital delays in acute stroke care. Neuroepidemiology 2001;20:65-76.

Executive Committee for the Asymptomatic Carotid Atherosclerosis Study: Endarterectomy for asymptomatic carotid artery stenosis. JAMA 1995;273:1421-1428.

Fagan SC, Bowes MP, Lyden PD, Zivin JA: Acute hypertension promotes hemorrhagic transformation in a rabbit embolic stroke model: Effect of labetalol. Exp Neurol 1998;150:153-158.

Farrell B, Godwin J, Richards S, Warlow C: The United Kingdom transient ischaemic attack (UK-TIA) aspirin trial: Final results. J Neurol Neurosurg Psychiatry 1991;54:1044-1054.

Feinberg W, Albers G, Barnett H, Biller J, Caplan $\mathrm{L}$, Carter L, et al: Guidelines for the management of transient ischemic attacks. From the Ad Hoc Committee on Guidelines for the Management of Transient Ischemic Attacks of the Stroke Council of the American Heart Association. Circulation 1994;89:2950-2965.
Ferro JM, Melo TP, Oliveira V, Crespo M, Canhão P, Pinto AN: A analysis of the admission delay of acute stroke. Cerebrovasc Dis 1994;4:7275.

Ferro JM, Pinto AN, Falcão I Rodrigues G, Ferreira J, Falcão F, Azevedo E, Canhão P, Melo TP, Rosas MJ, Oliveira V, Salgado AV: Diagnosis of stroke by the nonneurologist. A validation study Stroke 1998;29:1106-1109.

Fukuda H, Kitani M, Takahashi K: Body temperature correlates with functional outcome and the lesion size of cerebral infarction. Acta Neurol Scand 1999;100:385-390.

Fuster V, Ryden LE, Asinger RW, Cannom DS, Crijns HJ, Frye RL, Halperin JL, Kay GN, Klein WW, Levy S, McNamara RL, Prystowsky EN, Wann LS, Wyse DG, Gibbons RJ, Antman EM, Alpert JS, Faxon DP, Fuster V, Gregoratos G, Hiratzka LF, Jacobs AK, Russell RO, Smith SC, Klein WW, Alonso-Garcia A, Blomstrom-Lundqvist C, De Backer G, Flather M, Hradec J, Oto A, Parkhomenko A, Silber S, Torbicki A: ACC/AHA/ESC guidelines for the management of patients with atrial fibrillation: Executive summary. A report of the American College of Cardiology/American Heart Association Task Force on Practice Guidelines and the European Society of Cardiology Committee for Practice Guidelines and Policy Conferences (Committee to Develop Guidelines for the Management of Patients with Atrial Fibrillation) developed in collaboration with the North American Society of Pacing and Electrophysiology. J Am Coll Cardiol 2001;38:1231-1266.

de Gaetano G: Low-dose aspirin and vitamin $\mathrm{E}$ in people at cardiovascular risk: A randomised trial in general practice. Collaborative Group of the Primary Prevention Project. Lancet 2001;357:89-95.

Georgiadis D, Schwarz S, Aschoff A, Schwab S: Hemicraniectomy and moderate hypothermia in patients with severe ischemic stroke. Stroke 2002;33:1584-1588.

Georgilis K, Plomaritoglou A, Dafni U, Bassiakos Y, Vemmos K: Aetiology of fever in patients with acute stroke. J Intern Med 1999;246:203209.

Gerberding JL: Hospital-onset infections: A patient safety issue. Ann Int Med 2002;137:665.

Goldstein LB, Adams R, Becker K, Furberg CD, Gorelick PB, Hademenos G, Hill M, Howard G, Howard VJ, Jacobs B, Levine SR, Mosca L, Sacco RL, Sherman DG, Wolf PA, del Zoppo GJ: Primary prevention of ischemic stroke: A statement for healthcare professionals from the Stroke Council of the American Heart Association. Stroke 2001;32:280-299.

Grady D, Herrington D, Bittner V, Blumenthal R, Davidson M, Hlatky M, Hsia J, Hulley S, Herd A, Khan S, Newby LK, Waters D, Vittinghoff E, Wenger N: Cardiovascular disease outcomes during 6.8 years of hormone therapy: Heart and Estrogen/Progestin Replacement Study follow-up (HERS II). JAMA 2002;288:49-57.

Graham DI: Ischemic brain damage following emergency blood pressure lowering in hypertensive patients. Acta Med Scand 1982; 678(suppl):61-69.
Grau AJ, Buggle F, Schnitzler P, Spiel M, Lichy C, Hacke W: Fever and infection early after ischemic stroke. J Neurol Sci 1999;171:115-120.

Gray CS, Taylor R, French JM, Alberti KG, Venables GS, James OF, Shaw DA, Cartlidge NE, Bates D: The prognostic value of stress hyperglycaemia and previously unrecognized diabetes in acute stroke. Diabet Med 1987;4:237240

Grodstein F, Manson JE, Stampfer MJ: Postmenopausal hormone use and secondary prevention of coronary events in the nurses' health study. A prospective, observational study. Ann Intern Med 2001;135:1-8.

Grossman E, Messerli FH, Grodzicki T, Kowey P: Should a moratorium be placed on sublingual nifedipine capsules given for hypertensive emergencies and pseudoemergencies? JAMA 1996;276:1328-1331.

Hacke W, Brott T, Caplan L, Meier D, Fieschi C, von Kummer R, Donnan G, Heiss WD, Wahlgren NG, Spranger M, Boysen F, Marler JR: Thrombolysis in acute ischemic stroke: Controlled trials and clinical experience. Neurology 1999;53(7 suppl 4):S3-S14.

Hacke W, Kaste M, Fieschi C, von Kummer R, Davalos A, Meier D, Larrue V, Bluhmki E, Davis S, Donnan G, Schneider D, Diez Tejedor E, Trouillas P: Randomised double-blind placebo-controlled trial of thrombolytic therapy with intravenous alteplase in acute ischaemic stroke (ECASS II). Second EuropeanAustralasian Acute Stroke Study Investigators. Lancet 1998;352:1245-1251.

Hacke W, Kaste M, Fieschi C, Toni D, Lesaffre E, et al: Intravenous thrombolysis with recombinant tissue plasminogen activator for acute hemispheric stroke. The European Cooperative Acute Stroke Study (ECASS). JAMA 1995 ; 274:1017-1025.

Hacke W, Schwab S, Horn M, Spranger M, DeGeorgia M, von Kummer R: 'Malignant' middle cerebral artery territory infarction: Clinical course and prognostic signs. Arch Neurol 1996; 53:309-315.

Hacke W, Zeumer H, Ferbert A, Brückmann H, Del Zoppo G: Intra-arterial thrombolytic therapy improves outcome in patients with acute vertebrobasilar occlusive disease. Stroke 1988; 19:1216-1222.

Hajat C, Hajat S, Sharma P: Effects of poststroke pyrexia on stroke outcome: A meta-analysis of studies in patients. Stroke 2000;31:410-414.

Hankey GJ, Warlow CP: Treatment and secondary prevention of stroke: Evidence, costs, and effects on individuals and populations. Lancet 1999;354:1457-1463.

Hansson L, Zanchetti A, Carruthers S, Dahlof B, Elmfeldt D, Julius S, Menard J, Rahn KH, Wedel $\mathrm{H}$, Westerling $\mathrm{S}$ : Effects of intensive blood-pressure lowering and low-dose aspirin in patients with hypertension: principal results of the Hypertension Optimal Treatment (HOT) randomised trial. Lancet 1998;351: 1755-1762.

Harper G, Castleden CM, Potter JF: Factors affecting changes in blood pressure after acute stroke. Stroke 1994;25:1726-1729. 
Harraf F, Sharma AK, Brown MM, Lees KR, Vass RI, Kalra L: A multicentre observational study of presentation and early assessment of acute stroke. BMJ 2002;325:17.

Hart RG, Halperin JL, McBride R, Benavente O, Man-Son-Hing M, Kronmal RA: Aspirin for the primary prevention of stroke and other major vascular events: Meta-analysis and hypotheses. Arch Neurol 2000;57:326-332.

Hart RG, Sherman DG, Easton JD, Cairns J: Prevention of stroke in patients with nonvalvular atrial fibrillation. Neurology 1998;51:674681.

Hatashita S, Hoff JT, Ishii S: Focal brain edema associated with acute arterial hypertension. J Neurosurg 1986;64:643-649.

He K, Rimm EB, Merchant A, Rosner BA, Stampfer MJ, Willett WC, Ascherio A: Fish consumption and risk of stroke in men. JAMA 2002; 288:3130-3136.

Heart Protection Study Collaborative Group: MRC/BHF Heart Protection Study of cholesterol lowering with simvastatin in 20,536 highrisk individuals: A randomised placebo-controlled trial. Lancet 2002;360:7-22.

Hesse S: Locomotor therapy in neurorehabilitation. NeuroRehabilitation 2001;16:133-139.

Hommel M, for the FISS bis Investigators group Fraxiparin in acute ischaemic stroke. Cerebrovasc Dis 1998;8:63-68.

Horner J, Massey E, Riski J, et al.: Aspiration following stroke: Clinical correlates and outcome. Neurology 1988;38:1359-1362.

Hu FB, Willett WC: Optimal diets for prevention of coronary heart disease. JAMA 2002;288: 2569-2578.

Huff JS: Stroke mimics and chameleons. Emerg Med Clin North Am 2002;20:583-595.

Hughes RA, Barnes MP, Baron JC, Brainin M: Guidance for the preparation of neurological management guidelines by EFNS scientific task forces. Eur J Neurol 2001;6:549-550.

Hypothermia after Cardiac Arrest Study Group Mild therapeutic hypothermia to improve the neurologic outcome after cardiac arrest. $\mathrm{N}$ Engl J Med 2002;346:549-556.

Indredavik B, Bakke F, Solberg R, Rokseth R, Haaheim LL, Holme I: Benefit of a stroke unit: A randomized controlled trial. Stroke 1991;22: 1026-1031.

Indredavik B, Slordahl SA, Bakke F, Rokseth R, Haheim LL: Stroke unit treatment: Long-term effects. Stroke 1997;28:1861-1866.

International Stroke Trial Collaborative Group: The International Stroke Trial (IST): A randomised trial of aspirin, subcutaneous heparin, both, or neither among 19,435 patients with acute ischaemic stroke. Lancet 1997:349:15691581.

Inzitari D, Eliasziw M, Gates P, Sharpe BL, Chan RKT, Meldrum HE, Barnett HJM: The causes and risk of stroke in patients with asymptomatic internal-carotid-artery stenosis. N Engl J Med 2000;342:1693-1700.

Iranzo A, Santamaría J, Berenguer J, Sánchez M, Chamorro A: Prevalence and clinical importance of sleep apnea in the first night after cerebral infarction. Neurology 2002;58:911-916.
Italian Acute Stroke Study Group: Haemodilution in acute stroke: Results of the Italian Haemodilution Trial. Lancet 1988;1:318-321.

James P, Ellis CJ, Whitlock RML., McNeil AR, Henley J, Anderson NE: Relation between troponin $\mathrm{T}$ concentration and mortality in patients presenting with an acute stroke: Observational study. BMJ 2000;320:1502-1504.

Jansen PAF, Schulte BPM, Poels EFJ, Gribnau FWJ: Course of blood pressure after cerebral infarction and transient ischemic attack. Clin Neurol Neurosurg 1987;89:243-246.

Johansson BB: Brain plasticity and stroke rehabilitation. The Willis lecture. Stroke 2000;31:223230.

Jørgensen HS, Kammersgaard LP, Houth J, et al: Who benefits from treatment and rehabilitation in a stroke Unit? A community-based study. Stroke 2000;31:434-439.

Jørgensen H, Nakayama H, Raaschou H, Larsen K, Hübbe P, Olsen T: The effect of a stroke unit: Reductions in mortality, discharge rate to nursing home, length of hospital stay and cost. A community-based study. Stroke 1995;26: 1176-1182.

Jørgensen HS, Nakayama H, Raaschou HO, Olsen TS: Effect of blood pressure and diabetes on stroke in progression. Lancet 1994;16;344: 156-159.

Kalra E, Eade J: Role of stroke rehabilitation units in managing severe disability after stroke. Stroke 1995;26:2031-2034.

Kaplan N: Hypertensive emergencies. In: Kaplan $\mathrm{N}$ (ed): Clinical Hypertension. Baltimore, Williams and Wilkins, 1990.

Kasner SE, Wein T, Piriyawat P, Villar-Cordova CE, Chalela JA, Krieger DW, Morgenstern LB, Kimmel SE, Grotta JC: Acetaminophen for altering body temperature in acute stroke: A randomized clinical trial. Stroke 2002;33:130134.

Kaste M, Fogelholm R, Rissanen A: Economic burden of stroke and the evaluation of new therapies. Public Health 1998;112:103-112.

Kaste M, Palomaki H, Sarna S: Where and how should elderly stroke patients be treated? A randomized trial. Stroke 1995;26:249-253.

Kaste M, Roine RO: General stroke management and stroke units; in Grotta JC, Choi D, Mohr JP, Weir B, Wolf PA (eds): Stroke: Physiology, Diagnosis and Management. Philadelphia, Hartcourt Health Sciences, in press.

Kawachi I, Colditz GA, Stampfer MJ, WC, Manson JE, Rosner B, Speizer FE, Hennekens CH: Smoking cessation and decreased risk of stroke in women. JAMA 1993;269:232-236.

Kay R, Wong KS, Yu YL: Low molecular weight heparin for the treatment of acute ischaemic stroke. New Engl J Med 1995;333:1588-1593.

Khechinashvili G, Asplund K: Electrocardiographic changes in patients with acute stroke: A systematic review. Cerebrovasc Dis 2002;14:6776.

van Kooten F, Hoogerbrugge N, Naarding P, Koudstaal PJ: Hyperglycemia in the acute phase of stroke is not caused by stress. Stroke 1993;24:1129-1132.
Kothari R, Hall K, Brott T, Broderick J: Early stroke recognition: Developing and out-of-hospital NIH Stroke Scale. Acad Emerg Med 1997; 4:986-990.

Kramer AM, Steiner JF, Schenkler RE, et al: Outcomes and costs after hip fracture and stroke: A comparison of rehabilitation stettings. JAMA 1997;1277:396-404.

Kwan J, Sandercock P: In-hospital care pathways for stroke (Cochrane review); in: Cochrane $\mathrm{Li}$ brary, Issue 1, 2003. Update Software.

Langhorne P, Pollock A, for the Stroke Unit Trialists' Collaboration: What are the components of effective stroke unit care? Age Ageing 2002; 31:365-371.

Langhorne P, Stott DJ, Robertson L, MacDonald J, Jones L, McAlpine C, Dick F, Taylor GS, Murray G: Medical complications after stroke: A multicenter study. Stroke 2000;31:1223-1229.

Lee IM, Hennekens CH, Berger K, Buring JE, Manson JE: Exercise and risk of stroke in male physicians. Stroke 1999;30:1-6.

Leonardi-Bee J, Bath PMW, Philips SJ, Sandercock PAG, for the IST Collaborative Group: Blood pressure and clinical outcomes in the International Stroke Trial. Stroke 2002;33: 1315 .

Lewington S, Clarke R, Qizilbash N, et al: Age-specific relevance of usual blood pressure to vascular mortality: A meta-analysis of individual data for one million adults in 61 prospective studies. Lancet 2002;360:1903-2191.

Lindstrom E, Boysen G, Christiansen LW, Nansen BR, Nielsen PW: Reliability of Scandinavian neurological stroke scale. Cerebrovasc Dis 1991;1:103-107.

Lyden P, Brott T, Tilley B, Welch KM, Mascha EJ, Levine S, Haley EC, Grotta J, Marler J: Improved reliability of the NIH Stroke Scale using video training. NINDS TPA Stroke Study Group. Stroke 1994;25:2220-2226.

Mas JL, Arquizan C, Lamy C, Zuber M, Cabanes L, Derumeaux G, Coste J: Recurrent cerebrovascular events associated with patent foramen ovale, atrial septal aneurysm, or both. N Engl J Med 2001;345:1740-1746.

Meade T: Low dose warfarin and aspirin in preventing IHD. Practitioner 1998;242:799-803.

Meyer JS, Shimazu K, Fukuhuchi, Ohuchi T, Okamoto S, Koto A: Impaired neurogenic cerebrovascular control and dysautoregulation after stroke. Stroke 1973;4:169-186.

Miltner WH, Bauder H, Sommer M, Dettmers C, Taub E: Effects of constraint-induced movement therapy on patients with chronic motor deficits after stroke: A replication. Stroke 1999; 30:586-592.

Mohr JP, Thompson JL, Lazar RM, Levin B, Sacco RL, Furie KL, Kistler JP, Albers GW, Pettigrew LC, Adams HP Jr, Jackson CM, Pullicino $P$ : A comparison of warfarin and aspirin for the prevention of recurrent ischemic stroke. $\mathrm{N}$ Engl J Med 2001;345:1444-1451.

Mori K, Aoki A, Yamamoto T, Maeda M: Aggressive decompressive surgery in patients with massive hemispheric embolic cerebral infarction associated with severe brain swelling. Acta Neurochir (Wien) 2001;143:483-492. 
Neal B, MacMahon S, Chapman N: Effects of ACE inhibitors, calcium antagonists, and other blood-pressure-lowering drugs: results of prospectively designed overviews of randomised trials. Blood Pressure Lowering Treatment Trialists' Collaboration. Lancet 2000;356 1955-1964.

Norris J: Effects of cerebrovascular lesions on the heart. Neurol Clin 1983;1:87-101.

North American Symptomatic Carotid Endarterectomy Trial Collaborators: Beneficial effect of carotid endarterectomy in symptomatic patients with high-grade carotid stenosis. N Engl J Med 1991;325:445-453.

Olsen TS: Post-stroke epilepsy. Curr Atheroscler Rep 2001;3:340-344.

Oppenheimer S, Hachinski V: Complications of acute stroke. Lancet 1992;339:721-724.

Oppenheimer SM, Keden G, Martin WM: Leftinsular cortex lesions perturb cardiac autonomic tone in humans. Clin Auton Res 1996;6: 131-140.

PATS Collaborating Group: Post-stroke antihypertensive treatment study. A preliminary result. Chin Med J (Engl) 1995;108:710-717.

Peto R, Gray R, Collins R, Wheatley K, Hennekens C, Jamrozik K, Warlow C, Hafner B, Thompson E, Norton S: Randomised trial of prophylactic daily aspirin in British male doctors. $\mathrm{Br}$ Med J (Clin Res Ed) 1988;296:313-316.

Porteous GH, Corry MD, Smith WS: Emergency medical services dispatcher identification of stroke and transient ischemic attack. Prehosp Emerg Care 1999;3:211-216.

Power WJ: Acute hypertension after stroke: The scientific basis for treatment decisions. Neurology 1993;43:461-467.

PROGRESS Collaborative Group: Randomised trial of a perindopril-based blood-pressure-lowering regimen among 6,105 individuals with previous stroke or transient ischaemic attack. Lancet 2001;358:1033-1041.

Prough DS, Zornow MH: Hypertonic maintenance fluids for patients with cerebral edema: Does the evidence support a 'phase II' trial? Crit Care Med 1998;26:421-422.

Pulsinelli W, Levy D, Sigsbee B, Scherer P, Plum F: Increased damage after ischemic stroke in patients with hyperglycemia with or without established diabetes mellitus. Am J Med 1983 74:540-544.

Qizilbash N, Lewington SL, Lopez-Arrieta JM: Corticosteroids for acute ischaemic stroke. Cochrane Database Syst Rev 2002;(2): CD000064.

Qureshi AI, Suarez JI, Bhardwaj A, Mirski M, Schnitzer MS, Hanley DF, Ulatowski JA: Use of hypertonic $(3 \%)$ saline/acetate infusion in the treatment of cerebral edema: Effect on intracranial pressure and lateral displacement of the brain. Crit Care Med 1998;26:440-446.

Reith J, Jørgensen H, Pedersen P, Nakayama H, Raaschou H, Jeppesen L, Olsen T: Body temperature in acute stroke: Relation to stroke severity, infarct size, mortality and outcome. Lancet 1996;347:422-425.
Reynolds K, Lewis LB, Nolen JDL, Kinney GL, Sathya B, He J: Alcohol consumption and risk of stroke. A meta-analysis. JAMA 2003;289: 579-588.

Rieke K, Schwab S, Krieger D, von Kummer R, Aschoff A, Schuchardt V, Hacke W: Decompressive surgery in space-occupying hemispheric infarction: Results of an open, prospective trial. Crit Care Med 1995;23:1576-1587.

Righetti E, Celani MG, Cantisani TA, Sterzi R, Boysen G, Ricci S: Glycerol for acute stroke: A Cochrane systematic review. J Neurol 2002; 249:445-451.

Ringleb PA, Bertram M, Keller E, Hacke W: Hypertension in patients with cerebrovascular accident. To treat or not to treat? Nephrol Dial Transplant 1998;13:2179-2181.

Ronning OM, Guldvog B: Should stroke victims routinely receive supplemental oxygen? A quasi-randomized controlled trial. Stroke 1999;30: 2033-2037.

Roubin GS, New G, Iyer SS, Vitek JJ, Al-Mubarak N, Liu MW, Yadav J, Gomez C, Kuntz RE: Immediate and late clinical outcomes of carotid artery stenting in patients with symptomatic and asymptomatic carotid artery stenosis: A 5year prospective analysis. Circulation 2001; 103:532-537.

Rothwell PM, Eliasziv M, Gutnikov SA, Fox AJ, Taylor DW, Mayberg MR, Warlow CP, Barnett HJM: Analysis of pooled data from the randomized controlled trials of endarterectomy for symptomatic carotid stenosis. Lancet 2003;361:107-116

Rubins HB, Robins SJ, Collins D, Fye CL, Anderson JW, Elam MB, Faas FH, Linares E, Schaefer EJ, Schectman G, Wilt TJ, Wittes J: Gemfibrozil for the secondary prevention of coronary heart disease in men with low levels of highdensity lipoprotein cholesterol. Veterans Affairs High-Density Lipoprotein Cholesterol Intervention Trial Study Group. N Engl J Med 1999;341:410-418.

Schellinger PD, Fiebach JB, Hacke W (2003): Imaging-based decision making in thrombolytric therapy for ischemic stroke - Present state. Stroke 34:575-583.

Schwab S, Georgiadis D, Berrouschot J, Schellinger PD, Graffangino C, Mayer SA: Feasibility and safety of moderate hypothermia after massive hemispheric infarction. Stroke 2001;32:20332035.

Schwab S, Schwarz S, Spranger M, Keller E, Bertram M, Hacke W: Moderate hypothermia in the treatment of patients with severe middle cerebral artery infarction. Stroke 1998;29: 2461-2466.

Schwab S, Steiner T, Aschoff A, Schwarz S, Steiner $\mathrm{HH}$, Jansen O, Hacke W: Early hemicraniectomy in patients with complete middle cerebral artery infarction. Stroke 1998;29:1888-1893.

Schwarz S, Georgiadis D, Aschoff A, Schwab S: Effects of hypertonic $(10 \%)$ saline in patients with raised intracranial pressure after stroke. Stroke 2002;33:136-140
Schwarz S, Schwab S, Bertram M, Aschoff A, Hacke W: Effects of hypertonic saline hydroxyethyl starch solution and mannitol in patients with increased intracranial pressure after stroke. Stroke 1998;29:1550-1555.

Shackford SR, Zhuang J, Schmoker J: Intravenous fluid tonicity: effect on intracranial pressure, cerebral blood flow, and cerebral oxygen delivery in focal brain injury. J Neurosurg 1992;76: 91-98.

Shepherd J, Blauw GJ, Murphy MB, Bollen EL, Buckley BM, Cobbe SM, Ford I, Gaw A, Hyland M, Jukema JW, Kamper AM, Macfarlane PW, Meinders AE, Norrie J, Packard CJ, Perry IJ, Stott DJ, Sweeney BJ, Twomey C, Westendorp RG, for the PROSPER Study Group (PROspective Study of Pravastatin in the Elderly at Risk) : Pravastatin in elderly individuals at risk of vascular disease (PROSPER): A randomised controlled trial. Lancet 2002;360: 1623-1630.

Sherman DG, Atkinson RP, Chippendale T, Levin KA, Ng K, Futrell N, Hsu CY, Levy DE: Intravenous ancrod for treatment of acute ischemic stroke: the STAT study: a randomized controlled trial. Stroke Treatment with Ancrod Trial. JAMA 2000;283:2395-2403.

Shinton R, Beevers G: Meta-analysis of relation between cigarette smoking and stroke. BMJ 1989;298:789-794.

Silver F, Norris J, Lewis A, Hachinski V: Early mortality following stroke: A prospective review. Stroke 1984;15:492-496.

Sivenius J, Pyörälä K, Heinonen OP, Salonen J, Riekkinen P: The significance of intensity of rehabilitation in the recovery of stroke - A controlled trial. Stroke 1985;16:928-931.

Staessen JA, Wang JG, Thijs L: Cardiovascular protection and blood pressure reduction: A meta-analysis. Lancet 2001;358:1305-1315.

Steering Committee of the Physicians" Health Study Research Group: Final report on the aspirin component of the ongoing Physicians' Health Study. N Engl J Med 1989;321:129_ 135.

Stegmayr B, Vinogradova T, Malyutina S, et al: Widening gap of stroke between east and west. Eight-year trends in occurrence and risk factors in Russia and Sweden. Stroke 2000;31:2-8.

Steiner T, Mendoza G, De Georgia M, Schellinger P, Holle R, Hacke W: Prognosis of stroke patients requiring mechanical ventilation in a neurological critical care unit. Stroke 1997;28: 711-715.

Steiner T, Ringleb P, Hacke W: Treatment options for large hemispheric stroke. Neurology 2001; 57:S61-S68.

Strand T: Evaluation of long-term outcome and safety after hemodilution therapy in acute ischemic stroke. Stroke 1992;23:657-662.

Strand T, Asplund K, Eriksson S, Hagg E, Lithner F, Wester P: A non-intensive stroke unit reduces functional disability and the need for long-term hospitalization. Stroke 1985;16:29_ 34.

Straus SE, Majumdar SR, McAlister FA: New evidence for stroke prevention: Scientific review. JAMA 2002;288:1388-1395. 
Stroke Unit Trialists' Collaboration: Organised inpatient (stroke unit) care for stroke; in: Cochrane Library, Issue 1, 2002. Update Software.

Syrjanen J, Valtonen VV, Iivanainen M, Kaste M, Huttunen JK: Preceding infection as an important risk factor for ischaemic brain infarction in young and middle-aged patients. Br Med $\mathrm{J}$ (Clin Res Ed) 1988;296:1156-1160.

Taub E, Miller NE, Novack TA, et al: Technique to improve chronic motor deficit after stroke. Arch Phys Med Rehabil 1993;74:347-354.

Teasdale G, Jennett B: Assessment and prognosis of coma after head injury. Acta Neurochir (Wien) 1976;34:45-55.

The ATLANTIS, ECASS, and NINDS rt-PA Study Group Investigators: Better outcome with early stroke treatment: A pooled analysis of ATLANTIS, ECASS, and NINDS rt-PA stroke trials. Lancet 2003; in revision.

The Dutch TIA Trial Study Group: A comparison of two doses of aspirin ( $30 \mathrm{mg}$ vs. $283 \mathrm{mg}$ a day) in patients after a transient ischemic attack or minor ischemic stroke. N Engl J Med 1991; 325:1261-1266.

The EC/IC Bypass Study Group: Failure of extracranial-intracranial arterial bypass to reduce the risk of ischemic stroke. Results of an international randomised trial. N Engl J Med 1985; 313:1191-2000.

The European Ad Hoc Consensus Group: European strategies for early intervention in stroke. Cerebrovasc Dis 1996;6:315-324.

The European Ad Hoc Consensus Group: Optimizing intensive care in stroke: A European perspective. A report of an Ad Hoc Consensus Group meeting. Cerebrovasc Dis 1997;7:113128.

The European Atrial Fibrillation Study Group: Optimal oral anticoagulation therapy in patients with nonrheumatic atrial fibrillation and recent cerebral ischemia. N Engl J Med 1995; 333:5-10.

The European Carotid Surgery Trialists Collaborative Group: Risk of stroke in the distribution of an asymptomatic carotid artery. Lancet 1995; 345:209-212.

The Hemodilution in Stroke Study Group: Hypervolemic hemodilution treatment of acute stroke: Results of a randomized multicenter trial using pentastarch. Stroke 1989;20:317-323.

The Hypothermia after Cardiac Arrest Study Group: Mild therapeutic hypothermia to improve the neurologic outcome after cardiac arrest. N Engl J Med 2002;346:549-556.

The INDIANA (Individual Data Analysis of Antihypertensive Intervention Trials) Project $\mathrm{Col}-$ laborators: Effect of antihypertensive treatment in patients having already suffered from stroke: Gathering the evidence. Stroke 1997; 28:2557-2562.

The Multicenter Acute Stroke Trial - Europe Study Group: Thrombolytic therapy with streptokinase in acute ischaemic stroke. $\mathrm{N}$ Engl Med 1996;335:145-150.

The National Institute of Neurological Disorders and Stroke rt-PA Stroke Study Group (NINDS): Tissue plasminogen activator for acute ischemic stroke. N Engl J Med 1995;333 1581-1587.
The Stroke Prevention in Reversible Ischemia Trial (SPIRIT) Study Group: A randomized trial of anticoagulants versus aspirin after cerebral ischemia of presumed arterial origin. Ann Neurol 1997; 42:857-865.

The TOAST Publication Committee: Low molecular weight heparinoid, ORG 10172 and outcome after acute ischemic stroke. JAMA 1998; 279:1265-1272.

Thomas SH, Kociszewski C, Schwamm LH, Wedel SK: The evolving role of helicopter emergency medical services in the transfer of stroke patients to specialized centers. Prehosp Emerg Care 2002;6:210-204.

Thomassen L, Brainin M, Demarin V, Grond M, Toni D, Venables GS, for the EFNS Task Force on Acute Neurological Stroke Care: Acute stroke treatment in Europe: a questionnairebased survey on behalf of the EFNS task force on acute neurological stroke care. Eur J Neurol, in press.

Toni D, Fiorelli M, Gentile M, Bastianello S, Sacchetti ML, Argentino C, Pozzilli C, Fieschi C: Progressing neurological deficit secondary to acute ischemic stroke. A study on predictability, pathogenesis, and prognosis. Arch Neurol 1995;52:670-675.

Toni D, De Michele M, Fiorelli M, Bastianello S, Camerlingo M, Sacchetti ML, Argentino C, Fieschi C: Influence of hyperglycaemia on infarct size and clinical outcome of acute ischemic stroke patients with intracranial arterial occlusion. J Neurol Sci 1994;123:129-33.

Toni D, Sacchetti ML, Argentino C, Gentile M, Cavalletti C, Frontoni M, Fieschi C: Does hyperglycaemia play a role on the outcome of acute ischaemic stroke patients? J Neurol 1992; 239:382-386.

Turkington PM, Bamford J, Wanklyn P, Elliott MW: Prevalence and predictors of upper airway obstruction in the first $24 \mathrm{~h}$ after acute stroke. Stroke 2002;33:2037-2042.

Turner RC, Cull CA, Frighi V, Holman RR: Glycemic control with diet, sulfonylurea, metformin, or insulin in patients with type 2 diabetes mellitus: Progressive requirement for multiple therapies (UKPDS 49). UK Prospective Diabetes Study (UKPDS) Group. JAMA 1999; 281:2005-2012.

Unterberg AW, Kiening KL, Hartl R, Bardt T, Sarrafzadeh AS, Lanksch WR: Multimodal monitoring in patients with head injury: evaluation of the effects of treatment on cerebral oxygenation. J Trauma 1997;42:532-537.

Vandoni RE, Lironi A, Tschantz P: Bacteriuria during urinary tract catheterization: suprapubic versus urethral route: A prospective randomized trial. Acta Chir Belg 1994;94:12-16.

Vingerhoets F, Bogousslavsky J, Regli F, Van Melle G: Atrial fibrillation after acute stroke. Stroke 1993;24:26-30.

Viscoli CM, Brass LM, Kernan WN, Sarrel PM, Suissa S, Horwitz RI: A clinical trial of estrogen-replacement therapy after ischemic stroke. N Engl J Med 2001;345:1243-1249.

Wannamethee SG, Shaper AG, Whincup PH, Walker M: Smoking cessation and the risk of stroke in middle-aged men. JAMA 1995;274: 155-160.
Wardlaw JM: Overview of Cochrane thrombolysis meta-analysis. Neurology 2001;57(5 suppl 2): S69-S76.

Wardlaw J, Warlow C: Thrombolytic therapy for acute ischaemic stroke - The updated cochrane database of systemtic reviews metaanalysis. Cerebrovasc Dis 1999;9:124.

Weimar C, Glahn J, von Reutern GM, Kloth A, Busse O, Diener HC: Treatment of ischemic stroke in 14 neurologic stroke units. An evaluation of the stroke databank of the German Stroke Aid Foundation. Nervenarzt 2002b;73: 342-348.

Weimar C, Roth MP, Zillessen G, Glahn J, Wimmer ML, Busse O, Haberl RL, Diener HC; German Stroke Date Bank Collaborators: Complications following acute ischemic stroke. Eur Neurol 2002b;48:133-140.

Wein TH, Staub L, Felberg R, Hickenbottom SL, Chan W, Grotta JC, Demchuck AM, Groff J, Bartholomew LK, Morgenstern LB: Activation of emergency medical services for acute stroke in a nonurban population: The TLL Temple Foundation Stroke Project. Stroke 2000;31: 1925-1928

Weir CJ, Murray GD, Dyker AG, Lees KR: Is hyperglycaemia an independent predictor of poor outcome after acute stroke? Results of a long-term follow-up study. BMJ 1997;3;314: 1303-1306.

Werner C, Bardeleben A, Mauritz KH, Kirker S, Hesse S: Treadmill training with partial body weight support and physiotherapy in stroke patients: A preliminary comparison. Eur J Neurol 2002;9:639-644.

Wester P, Radberg J, Lundgreen B, Peltonen M: Factors associated with delayed admission to hospital and in-hospital delays in acute stroke and TIA. A prospective, multicenter study. Stroke 1999;30:40-48.

West of Scotland Coronary Prevention Study Group: Influence of pravastatin and plasma lipids on clinical events in the West of Scotland Coronary Prevention Study (WOSCOP). Circulation 1998;97:1440-1445.

WHO Task Force on Stroke and Other Cerebrovascular Disorders: Stroke -1989. Recommendations on stroke prevention, diagnosis, and therapy: Report of the WHO Task Force on Stroke and Other Cerebrovascular Disorders. Stroke 1989;20:1407-1431.

Wolf PA, D'Agostino RB, Kannel WB, Bonita R, Belanger AJ: Cigarette smoking as a risk factor for stroke. The Framingham Study. JAMA 1988;259:1025-1029.

Wolfe CDA, Giroud M, Kolomisnky-Rabas P, et al: Variations in stroke incidence and survival in 3 areas of Europe. Stroke 2000;31:2074-2079.

Yoon SS, Byles J: Preceptions in the general public and patients with stroke: A qualitative study. BMJ 2002;324:1065-1070.

Yusuf S, Sleight P, Pogue J, Bosch J, Davies R, Dagenais G: Effects of an angiotensin-converting-enzyme inhibitor, ramipril, on cardiovascular events in high-risk patients. The Heart Outcome Prevention Evaluation Study Investigators. N Engl J Med 2000;342:145-153. 